\title{
Paleohydrology reconstruction and Holocene climate variability in the South Adriatic Sea
}

\author{
G. Siani ${ }^{1}$, M. Magny ${ }^{2}$, M. Paterne ${ }^{3}$, M. Debret ${ }^{4}$, and M. Fontugne ${ }^{3}$ \\ ${ }^{1}$ IDES UMR 8148 CNRS, Département des Sciences de la Terre, Université Paris Sud, 91405 Orsay, France \\ ${ }^{2}$ Laboratoire de Chrono-Environnement, UMR 6249 du CNRS, UFR des Sciences et Techniques, 16 route de Gray, \\ 25030 Besançon, France \\ ${ }^{3}$ Laboratoire des Sciences du Climat et de l'Environnement (LSCE), Laboratoire mixte CNRS-CEA, Domaine du CNRS, \\ Avenue de la Terrasse, 91118 Gif sur Yvette, France \\ ${ }^{4}$ Laboratoire Morphodynamique Continentale et Côtière (M2C) (UMR CNRS 6143), \\ Université de Caen Basse-Normandie et Université de Rouen, 14000 Caen/76821 Mont-Saint-Aignan, France
}

Correspondence to: G. Siani (giuseppe.siani@u-psud.fr)

Received: 9 August 2012 - Published in Clim. Past Discuss.: 7 September 2012

Revised: 27 December 2012 - Accepted: 28 January 2013 - Published: 28 February 2013

\begin{abstract}
Holocene paleohydrology reconstruction is derived combining planktonic and benthic stable oxygen and carbon isotopes, sea surface temperatures (SSTs) and oxygen isotope composition of seawater $\left(\delta^{18} \mathrm{O}_{\mathrm{w}}\right)$ from a high sedimentation core collected in the South Adriatic Sea (SAS). Core chronology is based on 10 AMS ${ }^{14} \mathrm{C}$ measures on planktonic foraminifera and tephra layers. Results reveal two contrasted paleohydrological periods that reflect (i) a marked lowering of $\delta^{18} \mathrm{O}_{\mathrm{w}} /$ salinity during the early to mid-Holocene $(11.5 \mathrm{ka}$ to $6.3 \mathrm{ka})$, including the two-step sapropel S1 deposition, followed during the mid- to upper Holocene by (ii) a prevailing period of increased salinity and enhanced arid conditions in the South Adriatic Basin. Superimposed on these trends, short-term centennial-scale hydrological events punctuated the Holocene period in the SAS. During the early to mid-Holocene, two main SST coolings together with prominent $\delta^{18} \mathrm{O}_{\mathrm{w}}$ /salinity lowering delineate the sapropel S1 interruption and the post-sapropel phase between 7.3 to $6.3 \mathrm{ka}$. After $6 \mathrm{ka}$, centennial-scale $\delta^{18} \mathrm{O}_{\mathrm{w}}$ and G. bulloides $\delta^{13} \mathrm{C}$ lowering, mostly centered between 3 to $0.6 \mathrm{ka}$, reflect short-term hydrological changes related to more intensive runoff of the Po and/or Apennine rivers. These short-term events, even of lesser amplitude compared to the early to mid-Holocene period, may have induced a lowering of sea surface density and consequently reduced and/or inhibited the formation of deep bottom waters in the SAS. Comparison of the emerging centennial- to millennial-scale hydro-
\end{abstract}

logical record with previous climatic records from the central Mediterranean area and north of the Alps reveal possible synchronicities (within the radiocarbon-dating uncertainty) between phases of lower salinity in the SAS and periods of wetter climatic conditions around the north-central Adriatic Sea. Finally, wavelet analyses provide new clues about the potential origin of climate variability in the SAS, confirming the evidence for a mid-Holocene transition in the central Mediterranean climate and the dominance of a $\sim 1670$-yr periodicity after $6 \mathrm{ka}$, reflecting a plausible connection with the North Atlantic climate system.

\section{Introduction}

Because of its geographical positioning at the transition between two climatic zones (subtropical high pressure and subpolar depression), the Mediterranean region is particularly sensitive to regional impacts of climatic changes and extreme events (Giorgi and Lionello, 2008). Giving that, owing to the population density in this region, a forecast of the environmental response of the Mediterranean to future climate change is a crucial point, and investigations on climate archives covering periods of time longer than the instrumental record are required to refine a proper consideration of the natural climate variability. In this way, a better knowledge of the Holocene climate variability in the Mediterranean area 
is an essential step to provide new insights for predictive climate models.

Over the last decades, the Mediterranean region has been the focus of studies carried out on the complex interactions between the North Atlantic and North Africa tropical climatic systems (Zolitschka et al., 2000). More generally, these interactions accounted for variations (1) of the position of the westerlies and intensity of the African monsoon systems, and subsequently (2) the quantity of precipitation brought to this zone (Bar-Matthews et al., 2000). In addition, proxy reconstructions from Holocene continental and marine archives have suggested periodicities of the climate at decadal, secular and millennial timescales (Kallel et al., 1997a, b; Cheddadi et al., 1997; Roberts et al., 2001; Sadori and Narcisi, 2001; Rohling et al., 2002; Magny et al., 2003, 2006; Frigola et al., 2007; Marino et al., 2009) related to changes in Earth's orbital parameters and solar activity (Mayewski et al., 2004; Magny et al., 2007).

The South Adriatic Sea (SAS) is an area characterized by very high sedimentation rates that favor the analysis of Holocene climatic changes at centennial temporal resolution and the interactions between strong atmospheric forcing, precipitation and river runoff (Fontugne et al., 1989; Asioli et al., 2001; Oldfield et al., 2003; Sangiorgi et al., 2002, 2003; Piva et al., 2008). Moreover, this basin is one of the sources of modern deep-sea water formation, playing a key role in changes in the thermohaline circulation in the Mediterranean Sea (Pinardi and Masetti, 2000), and in the North Atlantic Ocean (Schönfeld and Zahn, 2000; Rogerson et al., 2005; Voelker et al., 2006).

Here we present a highly detailed reconstruction of the Holocene paleohydrology at a decadal-scale time resolution, from a high-sedimentation deep-sea core recovered in the SAS. Past circulation dynamic was assessed by sea surface temperature (SST) using the modern analog technique (MAT) coupled with oxygen and carbon isotope measurements performed on the planktonic foraminifera Globigerina bulloides and on the benthic foraminifera Cibicidoides pachydermus. Oxygen isotopes on the planktonic foraminifera $G$. bulloides and SST reconstructions allow for derivation of changes in the oxygen isotope composition of seawater $\left(\delta^{18} \mathrm{O}_{\mathrm{w}}\right)$, a proxy for salinity, providing clues on the freshwater budget and paleoceanographic changes in this basin. Our climatic investigation benefits from a very detailed chronological framework based on a large data set of AMS ${ }^{14} \mathrm{C}$ dating of monospecific planktonic foraminifera coupled to tephra layers (Siani et al., 2004, 2010).

In addition, because of the high timescale resolution, results were compared to marine and continental climate records from the central and eastern Mediterranean areas and north of the Alps in west-central Europe. Finally, wavelet analysis of the paleohydrological record was used to shed light on the possible driver and timing of the Holocene climate variability in the SAS.

\section{Studied area and modern circulation pattern in the Adriatic Sea}

The Adriatic Sea is a semi-enclosed basin detached from the Ionian Sea by the sill of the Otranto Strait $(780 \mathrm{~m})$. It is characterized to the north by a wide continental shelf sloping down to $100 \mathrm{~m}$ and by the shallow Pelagosa sill ( $\sim 120 \mathrm{~m}$ ) that separates the middle basin from the southernmost part, featured by the largest topographic depression of about 1200 m, the South Adriatic Pit (Fig. 1).

The Adriatic Sea is situated between the subtropical highpressure zone and the mid-latitude belt, in which winds move generally from west to east with sharp seasonal differences (Orlic et al., 1992). In winter, the dominant winds are the Bora blowing from the northeast and the Sirocco from the south, whereas during summer the general atmospheric circulation is dominated by the westerlies.

The modern oceanic circulation pattern depends on several factors including (1) episodic atmospheric events (i.e. Bora) that produce wind-driven currents promoting intense mixing and dense water formation, (2) freshwater discharge characterized by strong river runoff from the Po and numerous surrounding rivers, and (3) exchange flow with the Ionian Sea through the Otranto Strait. This produces a seasonal cyclonic circulation with a northerly inflow component, flowing along the eastern coast, represented by the Mediterranean Surface Water (MSW) from the Ionian Basin through the Otranto Strait and by a second southerly outflow component, i.e. the Western Adriatic Current (WAC) along the western coast (Artegiani et al., 1997; Poulain, 1999). The outflow is reinforced by a high amount of freshwater, nutrients and suspended matter through the Po River with an annual mean freshwater discharge rate of about $1500 \mathrm{~m}^{3} \mathrm{~s}^{-1}$ (Raicich, 1996). In winter, a further inflow of more saline Levantine Intermediate Water (LIW) originating from the eastern Mediterranean Sea spread along the eastern Adriatic coast. The mixing between LIW and MSW in the South Adriatic Pit forms the Eastern Mediterranean Deep Water (EMDW) that represents the major source of the densest water in the eastern Mediterranean Sea (Artegiani et al., 1989; Manca et al., 2002). In this context, temperature changes, increased terrestrial freshwater runoff and/or a slowdown of incoming saltier LIW in the Adriatic Sea could affect the sea surface hydrology and consequently reduce and/or inhibit the formation of deep waters in the basin.

\section{Material and methods}

Core MD90-917 was collected during the PROMETE II cruise by the French R/V Marion Dufresne in the deep South Adriatic Basin $\left(41^{\circ} 17^{\prime} \mathrm{N}, 17^{\circ} 37^{\prime} \mathrm{E}, 1010 \mathrm{~m}\right.$; Fig. 1). Coring at this site recovered a fairly uniform succession of $21 \mathrm{~m}$ of gray to brown carbonaceous clays, including a black layer in the upper part of the core that referred to the two sub-units 


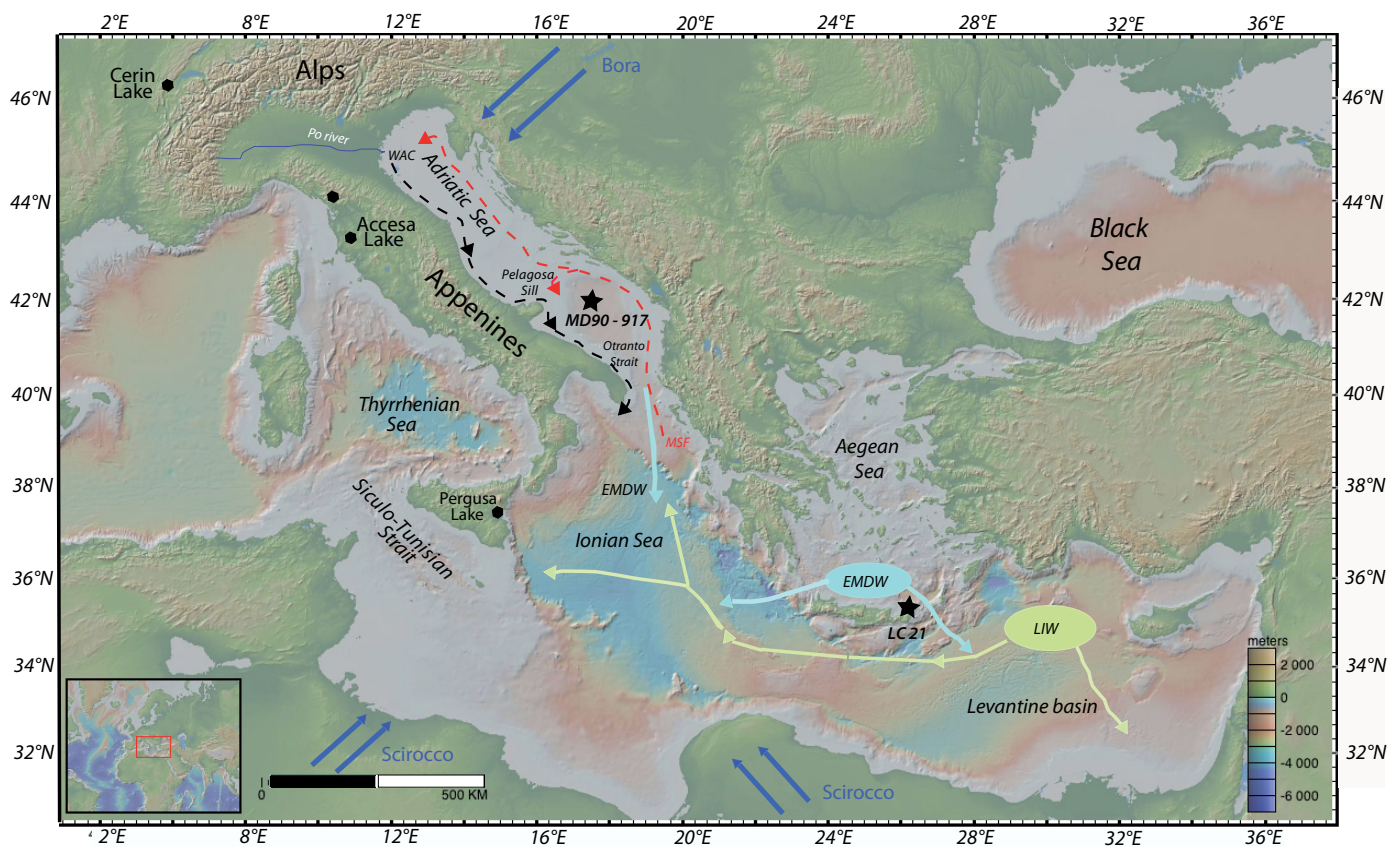

Fig. 1. Location of the studied core MD90-917 and reference sites in the Mediterranean and north of the Alps. Core LC-21 (Rohling et al., 2002; Marino et al., 2009), Cerin Lake (Magny et al., 2011a), Accesa Lake (Magny et al., 2007), Pergusa Lake (Magny et al., 2012a). Blue arrows correspond to the main low-level winds (Bora and Scirocco). LIW = Levantine Intermediate water, EMDW $=$ Eastern Mediterranean Deep Water, MSF $=$ Mediterranean Surface Water, WAC $=$ Western Adriatic Current.

of the sapropel S1 and several ash layers (Siani et al., 2004). Sapropel S1 was deposited during the most recent period of stagnation in the eastern Mediterranean Sea between ca. 10 and 6 cal.ka BP (Rossignol-Strick et al., 1982; Rohling, 1994; Fontugne et al., 1994; Mercone et al., 2000; De Lange et al., 2008) and is characterized in the studied core by two levels of black-gray sediments from $229 \mathrm{~cm}$ to $255 \mathrm{~cm}$ (S1a and S1b), separated by a thin horizon of white hemipelagic ooze between $239 \mathrm{~cm}$ and $247 \mathrm{~cm}$ corresponding to the sapropel interruption (Fig. 2). For this study, the first $3 \mathrm{~m}$ of the core have been analyzed.

Oxygen and carbon isotope measurements $\left(\delta^{18} \mathrm{O}, \delta^{13} \mathrm{C}\right)$ were performed on the planktonic foraminifera $G$. bulloides and on the benthic foraminifera $C$. pachydermus, respectively, in the size fraction $(250-315 \mu \mathrm{m})$. The foraminifera $\delta^{18} \mathrm{O}$ is a function of both temperature and seawater $\delta^{18} \mathrm{O}$ $\left(\delta^{18} \mathrm{O}_{\mathrm{w}}\right)$, the latter reflecting mainly the changes of the global ice volume and local hydrological variations (Shackleton, 1974). The $\delta^{13} \mathrm{C}$ measured on planktonic foraminifera is an ideal proxy for understanding the carbon relationships among the land, atmosphere and sea, as well as the carbon exchange within the water column. On the other hand, the $\delta^{13} \mathrm{C}$ signal of benthic foraminifera gives information on the oceanic carbon cycle, and it is largely used to reconstitute past oceanic circulation changes as well as organic carbon flux in the oceanic bottom waters (Blanc and Duplessy, 1982; Duplessy et al., 1988; Sarnthein et al., 1994; Mackensen et al., 2001; Curry and Oppo, 2005).
In this study, 35 additional stable isotope analyses of planktonic foraminifera integrate the previously published data set (Siani et al., 2010) with a sampling resolution every $2 \mathrm{~cm}$. By contrast, due to the lesser occurrence of the oxic benthic foraminifera species along the core, a lower sampling resolution was obtained for oxygen and carbon isotope measurements on the epibenthic foraminifera $C$. pachydermus. Isotope analyses were performed at LSCE on a Finnigan D+ and Elementar Isoprime mass spectrometers. Results are expressed versus Vienna Pee Dee Belemnite standard (VPDB), in per mil with respect to NBS-19 calcite standard $\left(\delta^{18} \mathrm{O}=-2.20 \%\right.$ and $\left.\delta^{13} \mathrm{C}=+1.95 \% o\right)$. The mean external reproducibility $(1 \sigma)$ of carbonate standards is $\pm 0.06 \%$ o for $\delta^{18} \mathrm{O}$ and $\pm 0.04 \%$ for $\delta^{13} \mathrm{C}$; measured NBS- $18 \delta^{18} \mathrm{O}$ is $-23.2 \pm 0.2 \%$ o VPDB, and $\delta^{13} \mathrm{C}$ is $-5.0 \pm 0.1 \%$ VPDB. The samples were cleaned in a methanol ultrasonic bath for a few seconds and roasted under vacuum at $380^{\circ} \mathrm{C}$ for $45 \mathrm{~min}$ prior to analysis, following the procedure described by Duplessy (1978).

Sea surface temperatures (SSTs) were determined using planktonic foraminifera assemblages. Each foraminifera sample ( $>150 \mu \mathrm{m}$ fraction) was split into 300-1000 individuals for identification and counting. The SSTs were calculated by applying the modern analog technique (Prell, 1985), using the Mediterranean database (Kallel et al., 1997a) and the PaleoAnalogs software (Theron et al., 2004). As for the oxygen isotope record, 35 additional SST estimates have been carried out along the first $3-\mathrm{m}$ of the core to complete 


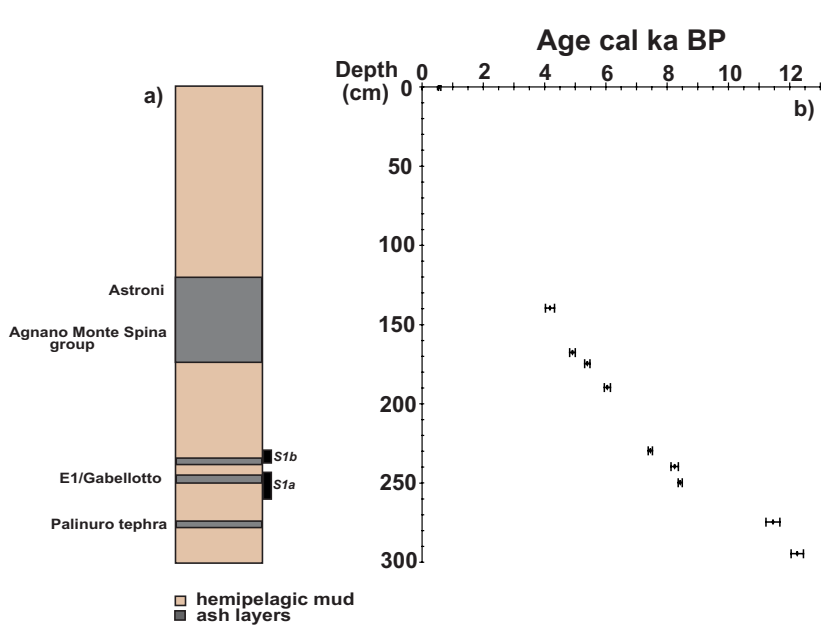

Fig. 2. (a) Lithology as a function of depth of the core MD90-917. S1a and S1b refer to the two-step sapropel units. Gray lines mark tephra layers recovered along the core and their origin. (b) Agedepth relation for core MD90-917 based on 10 linearly interpolated ${ }^{14} \mathrm{C}$ AMS dates. ${ }^{14} \mathrm{C}$ ages are shown in calendar ka BP including a reservoir ${ }^{14} \mathrm{C}$ age correction as indicated in Siani et al. (2000, 2001).

the previous record of Siani et al. (2010). Reliability of SSTs is estimated using a square chord distance test (dissimilarity coefficient) that represents the mean degree of similarity between the sample and the best ten modern analogs. When the dissimilarity coefficient is lower than 0.25 , the reconstruction is considered to be of good quality (Overpeck et al., 1985). Besides winter and summer SST estimates, we have derived SSTs during April-May as the isotopic temperature of G. bulloides and the April-May Levitus SST are best correlated (Kellel et al., 1997a; Levitus, 1982, Levitus and Boyer, 2004). These results coincide with the most productive period during the spring and the contemporary bloom of G. bulloides in the Mediterranean Sea (Pujol and VergnaudGrazzini, 1995). Good dissimilarity coefficients generally $<0.25$ are calculated in core MD90-917 with an average value at 0.15 . The calculated mean standard deviation of SST estimates is $\sim 0.7^{\circ} \mathrm{C}$.

Sea surface salinity as expressed by the local seawater $\delta^{18} \mathrm{O}_{\mathrm{w}}$ was determined following the method proposed by Duplessy et al. (1991). SST and planktonic foraminifera $\delta^{18} \mathrm{O}$ records were used to estimate the surface water $\delta^{18} \mathrm{O}_{\mathrm{w}}$ variations by solving the paleotemperature equation of Shackleton (1974), using the April-May SSTs that represent the period when G. bulloides species deposited their shell in isotopic equilibrium with ambient water (Kallel et al., 1997a):

$$
\begin{aligned}
T\left(\mathrm{C}^{\circ}\right) & =16.9-4.38\left(\delta^{18} \mathrm{O}_{\text {calcite }}-\delta^{18} \mathrm{O}_{\mathrm{w}}+0.27\right) \\
& +0.1\left(\delta^{18} \mathrm{O} \text { foraminifera }-\delta^{18} \mathrm{O}_{\mathrm{w}}+0.27\right)^{2} .
\end{aligned}
$$

$\delta^{18} \mathrm{O}_{\mathrm{w}}$ variations reflect both the global change of the mean oceanic isotopic composition due to continental ice volume changes and the local change due to the variations of the freshwater inflow and evaporation balance. Local $\delta^{18} \mathrm{O}_{\mathrm{w}}$ changes were then obtained by subtracting the effect of continental ice melting on global seawater $\delta^{18} \mathrm{O}$. The latter is assumed to be equal to the deglacial sea level curve of Lambeck and Chappell (2001) multiplied by a constant coefficient of $1.1 \%$ o/ $130 \mathrm{~m}$ from Waelbroeck et al. (2002). We did not convert the $\delta^{18} \mathrm{O}_{\mathrm{w}}$ values into salinity units because of uncertainty resulting from possible temporal changes in the slope of the $\delta^{18} \mathrm{O}_{\mathrm{w}} /$ salinity relationship at the studied core site (Kallel et al., 1997b). The accuracy of the $\delta^{18} \mathrm{O}_{\mathrm{w}}$ estimates depends primarily on that of the SST estimates. Taking into account the $0.07 \%$ error due to mass spectrometer measurements and the mean standard deviation on SSTs $\left(\sim 1^{\circ} \mathrm{C}\right.$ error for SST estimates would result in a $0.23 \%$ o error in the calculated $\delta^{18} \mathrm{O}_{\mathrm{w}}$ value), the averaged error on the $\delta^{18} \mathrm{O}_{\mathrm{w}}$ estimate is $0.18 \pm 0.06$ for the South Adriatic Sea $\left(\sigma \operatorname{SSTsv}=0.7^{\circ} \mathrm{C}\right)$.

Wavelet analysis (WA) is a technique used for the identification of spectral signatures in paleoclimate time series, with the particular advantage of describing non-stationarities, i.e. discontinuities and changes in frequency or magnitude (Torrence and Compo, 1998). In contrast to classical Fourier analysis, the local wavelet spectrum provides a direct visualization of the changing statistical properties in stochastic processes over time. Here, the Morlet wavelet (a Gaussianmodulated sin wave) was chosen for the continuous wavelet transform. The data series was zero-padded to twice the data length in order to avoid edge effects and spectral leakage produced by the finite length of the time series. The statistical significance of peaks in the local wavelet spectrum was assessed using a Monte Carlo simulation. Singular spectrum analysis was employed to estimate and separate background noise. Autoregressive modeling was used to determine the $\mathrm{AR}(1)$ stochastic process against which the initial time series was to be tested; $\operatorname{AR}(1)$ background noise is red noise $(A R(1)>0)$. Black lines on the scalogram define $95 \%$ confidence. By using wavelet reconstruction it is possible to reconstruct the signal in various spectral bands. In this way, we use it to reconstruct the millennial-scale component in the paleoclimatic data.

\section{Chronological framework}

The age model, based on 10 AMS ${ }^{14} \mathrm{C}$ measurements performed on monospecific planktonic foraminifera in the size fraction $>150 \mu \mathrm{m}$, was previously given in Siani et al. (2010; Fig. 2). We do not take into account ageing of ${ }^{14} \mathrm{C}$ dates by bioturbation processes because of the high sedimentation rate in the core, estimated at $35 \mathrm{~cm} \mathrm{ka}^{-1}$ for the Holocene period and at $20 \mathrm{~cm} \mathrm{ka}^{-1}$ during the sapropel S1 interval (Mercone et al., 2000; Charbit et al., 2002). This results in a time resolution of sampling intervals for $\delta^{18} \mathrm{O}$ on planktonic foraminifera G. bulloides, SST and $\delta^{18} \mathrm{O}_{\mathrm{w}}$ analyses of $\sim 40 \mathrm{yr}$ during the Holocene and $\sim 75 \mathrm{yr}$ during the 
sapropel S1, respectively. The conventional radiocarbon ages have been subsequently converted into calendar ages, based on INTCAL04 (Reimer et al., 2004) using the ${ }^{14} \mathrm{C}$ calibration software CALIB 6. The calibration integrates a marine ${ }^{14} \mathrm{C}$ reservoir age correction $\mathrm{R}(\mathrm{t})$ at $390 \pm 85 \mathrm{yr}$ according to Siani et al. (2000, 2001). In addition, the age model is complemented by five tephra layers previously identified along the first $3 \mathrm{~m}$ of the core, providing further dating points and allowing for a better and more precise chronological framework covering the last 11500 cal. yr BP (Siani et al., 2004). In this study, hereafter, all ages are discussed as cal. ka BP.

\section{Results}

\subsection{Sea surface temperature record}

During the Holocene, South Adriatic April-May SST estimates range from $18^{\circ} \mathrm{C}$ to $13^{\circ} \mathrm{C}$ (Fig. 3b). The Younger Dryas-Holocene transition was recorded at $\sim 11.5 \mathrm{ka}$, and the highest SSTs were achieved during the Holocene climatic optimum at $\sim 8.4 \mathrm{ka}$ coeval to the sapropel S1a deposit. Conversely, during the sapropel S1b SSTs are slightly lower and similar to the modern ones. Then, two main cold spells mark the $\mathrm{S} 1$ interruption at $8.2 \mathrm{ka}$ and after the $\mathrm{S} 1 \mathrm{~b}$ deposit between 7.3 to $6.3 \mathrm{ka}$ respectively. Interruption of the sapropel formation has been previously observed in the Adriatic Sea (Bottema and Van Straaten, 1966; Mangini and Schlosser, 1986; Fontugne et al., 1989; Sangiorgi et al., 2003) and a short duration estimated at around $200 \mathrm{yr}$ (Rohling et al., 1997). This short event was also recorded by marine and terrestrial pollen records from the Northern Aegean Sea (Kotthoff et al., 2008a, b; Pross et al., 2009) and more recently in the far south of this basin by artificial neural networks (ANN) based summer SST estimations on planktonic foraminifera abundance (Fig. 4c; Marino et al., 2009). After the cold 8.2ka event, SSTs rise by about $3{ }^{\circ} \mathrm{C}$, displaying similar values to the modern ones, followed by a short-lived centennial lighter cooling $\left(\sim 1^{\circ} \mathrm{C}\right)$ between 7.8 and $7.5 \mathrm{ka}$ at the time of sapropel S1b (Fig. 3b).

A more pronounced SST cooling between $7.3 \mathrm{ka}$ and $6.3 \mathrm{ka}$ by some $4{ }^{\circ} \mathrm{C}$ marks the post-sapropel S1b deposition even though the general cooling trend is interrupted by two short centennial warm spells centered at 7.1 and $6.5 \mathrm{ka}$ respectively. These cooling phases are marked by the dominance of the sub-polar planktonic foraminifera Neogloboquadrina pachyderma right coiling, as previously observed in the Adriatic Sea (Giunta et al., 2003; Sangiorgi et al., 2003) and in the Tyrrhenian Sea by Kallel et al. (1997a). By contrast, the alkenone SST reconstructions obtained in the close South Adriatic core AD91-17 indicate no cooling during the sapropel interruption or between 7.3 and $6.3 \mathrm{ka}$ (Sangiorgi et al., 2003). This discrepancy between the alkenone SST reconstructions and the MAT could be due to differences in the growing season of the calcareous nannoplankton assemblages as already pointed out by Sangiorgi et al. (2003).

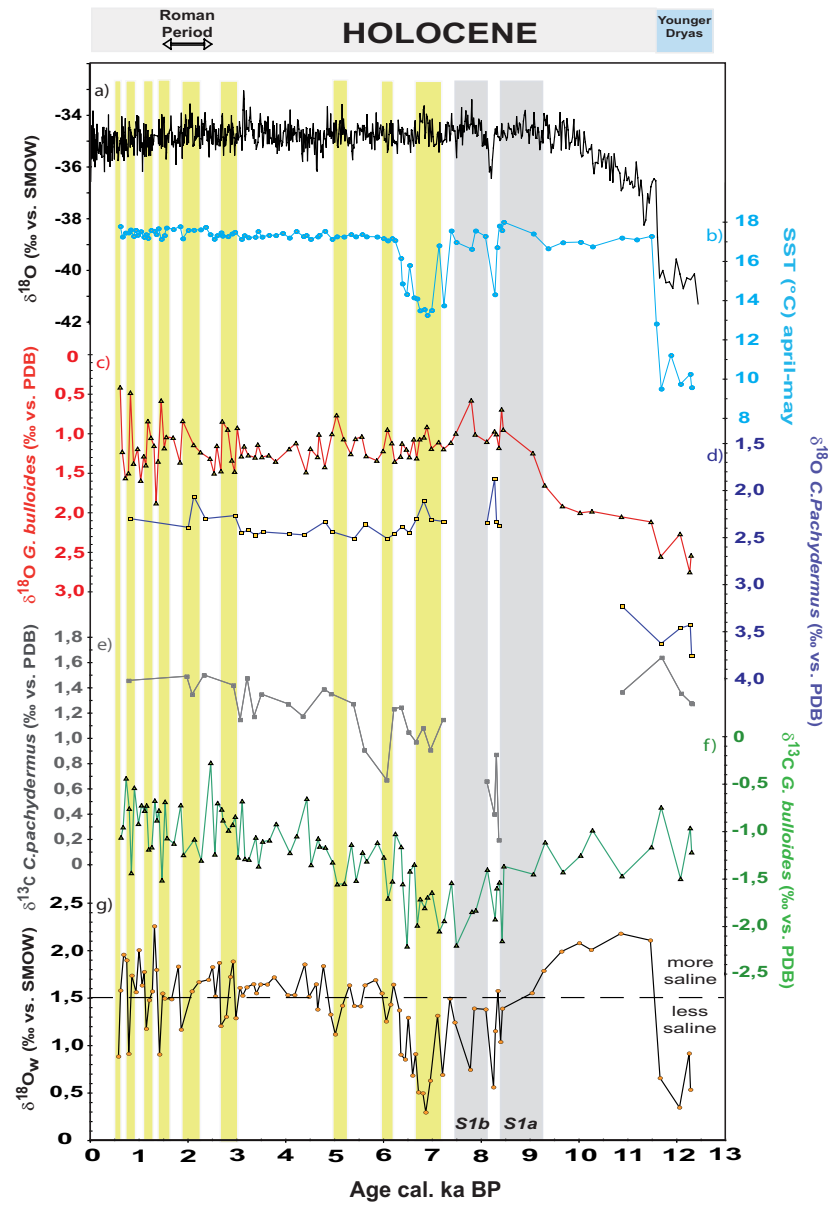

Fig. 3. Climatic record from core MD90-917 and comparison with Greenland ice core since the Younger Dryas-Holocene transition vs. age (cal. ka BP): (a) oxygen isotope record from GISP 2 ice core. (b) April-May sea surface temperature as determined by the modern analog technique (MAT). (c) $\delta^{18} \mathrm{O}$ of the planktonic foraminifera Globigerina bulloides. (d) $\delta^{18} \mathrm{O}$ of the benthic foraminifera Cibicidoides pachydermus. (e) $\delta^{13} \mathrm{C}$ of the benthic foraminifera Cibicidoides pachydermus. (f) $\delta^{13} \mathrm{C}$ of the planktonic foraminifera Globigerina bulloides. (g) Calculated sea water $\delta^{18} \mathrm{O}$ record $\left(\delta^{18} \mathrm{O}_{\mathrm{w}}\right)$ generated from the SST by MAT and G. bulloides $\delta^{18} \mathrm{O}$ by solving the paleotemperature equation of Shackleton (1974); dashed line corresponds to modern $\delta^{18} \mathrm{O}_{\mathrm{w}}$ values in the South Adriatic after Pierre (1999). S1a and S1b refer to the two-step sapropel $\mathrm{S} 1$ deposition. Yellow bars indicate low $\delta^{18} \mathrm{O}_{\mathrm{w}} /$ salinity values.

However, even though South Adriatic SST reconstructions by MAT are in agreement with the Tyrrhenian Sea ones, they differ considering that the SST decrease in the Tyrrhenian Sea cannot be referring to the sapropel (s.s.) deposit due to the absence of a well-marked sapropelic horizon in this basin (Kallel et al., 1997a). Finally, a further SST increase occurred at $6.8 \mathrm{ka}$, and temperature has remained on a stable trend since about $6.3 \mathrm{ka}$ displaying mean values similar to those observed today (Fig. 3b). 


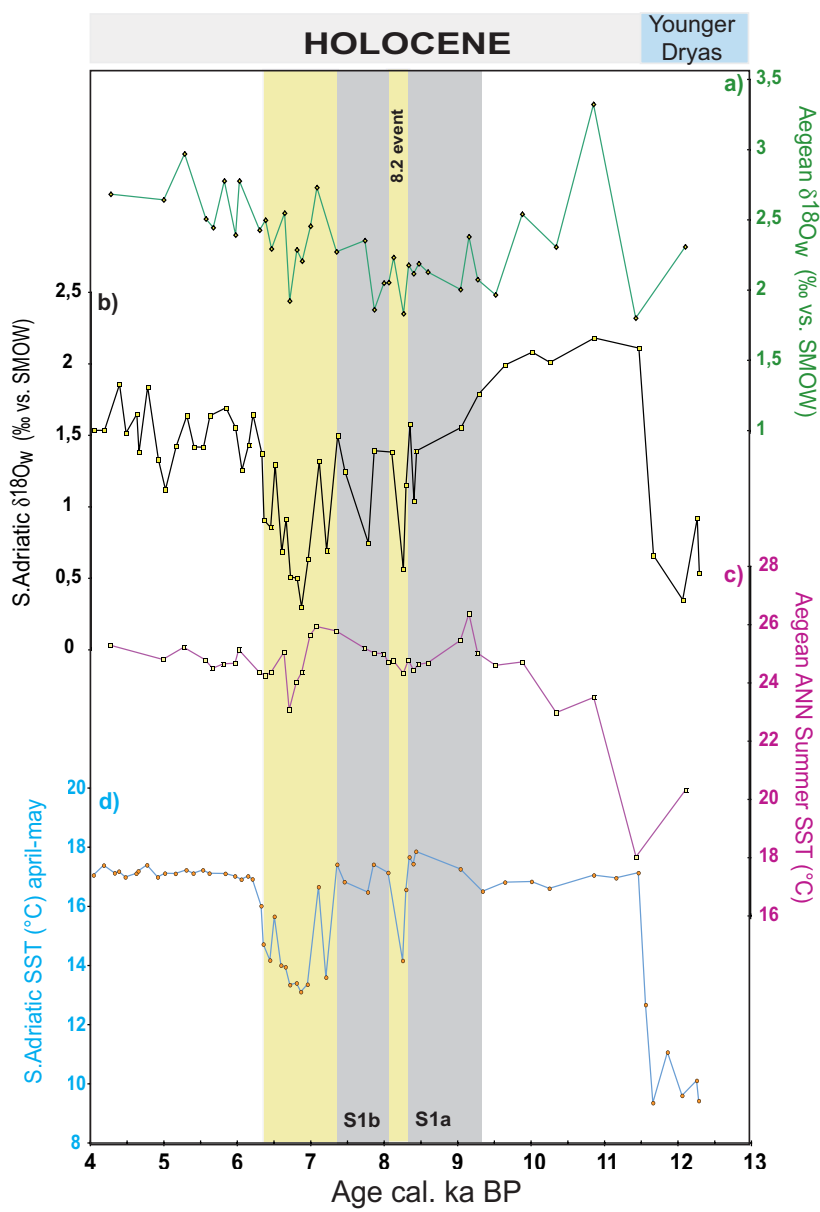

Fig. 4. Comparison between the South Adriatic Sea (this study) and the Aegean Sea climatic record from core LC-21 (Rohling et al., 2002; Marino et al., 2009) vs. age (cal. ka BP). (a) Aegean Sea $\delta^{18} \mathrm{O}_{\mathrm{w}}$ record. (b) South Adriatic $\delta^{18} \mathrm{O}_{\mathrm{w}}$ record. (c) Artificial neural networks (ANN) based summer SST estimations in the Aegean Sea. (d) April-May South Adriatic Sea surface temperature by MAT. Gray areas refer to S1a and S1b sapropel deposition and yellow areas to the $S 1$ interruption and post-S1b phase in the South Adriatic Sea.

\subsection{Stable isotopes}

The $\delta^{18} \mathrm{O}$ records from core MD90-917 show values range from 0.4 to $2.5 \%$ for G. bulloides and from $1.8 \%$ o to $2.6 \%$ for C. pachydermus (Fig. 3c, d). A shift from 11.5 ka to $8.4 \mathrm{ka}$ toward depleted $\delta^{18} \mathrm{O}$ in the G. bulloides values marks the second step of the deglaciation. In detail, the G. bulloides $\delta^{18} \mathrm{O}$ record shows the highest values of $\sim 2.5$ to $2 \%$ at the Younger Dryas-Holocene transition $(11.5 \mathrm{ka})$, whereas the lowest values are at $7.8 \mathrm{ka}$ and $0.6 \mathrm{ka}$ respectively. The $\delta^{18} \mathrm{O}$ record of the epibenthic species $C$. pachydermus exhibits a feature similar to the G. bulloides $\delta^{18} \mathrm{O}$ one with the highest values centered at $11.5 \mathrm{ka}$ and the lowest during the sapropel $\mathrm{S} 1$ interruption at $8.2 \mathrm{ka}$ as displayed by a $0.5 \%$ oxygen isotope depletion (Fig. 3d). Nonetheless, no data are avail- able during the sapropel S1a and S1b due to anoxic conditions, hence the lack of benthic foraminifera generally used for isotope analyses.

Similarly, the most striking characteristic of the $\delta^{13} \mathrm{C}$ Holocene records is the high variability with values ranging from -2.2 to $-0.3 \%$ for $G$. bulloides and between $1.6 \%$ o and $0.2 \%$ or $C$. pachydermus (Fig. 3e, f). A general decreasing trend marks the G. bulloides $\delta^{13} \mathrm{C}$ record from $11.5 \mathrm{ka}$ to $6.3 \mathrm{ka}$ with the higher values centered at the onset of the Holocene and the more depleted values characterizing the period of the sapropel S1 deposition (Fig. 3e). The C. pachydermus $\delta^{13} \mathrm{C}$ record displays a similar trend even though, as seen above, the lack of oxic benthic foraminifera during the sapropel S1 precludes a continuous bottom waters hydrological record (Fig. 3f). Since then, a rise of $\delta^{13} \mathrm{C}$ values for both planktonic and benthic foraminifera records characterizes the post-sapropel period (Fig. 3e, f). However, irrespective of their general trends, both $\delta^{18} \mathrm{O}$ and $\delta^{13} \mathrm{C}$ records display short-term centennial- to millennial-scale fluctuations throughout the Holocene period.

\subsection{Sea surface $\delta^{18} O_{w} /$ salinity record}

$\delta^{18} \mathrm{O}_{\mathrm{w}}$ values display a high variability between $2.2 \%$ and $0.3 \%$ over the last $11.5 \mathrm{ka}$ (Fig. $3 \mathrm{~g}$ ). The highest $\delta^{18} \mathrm{O}_{\mathrm{w}}$ values occurred at the early and upper Holocene, while the lowest ones are associated with (i) the sapropel S1 deposition, (ii) the cold event at $8.2 \mathrm{ka}$ and (iii) the post-sapropel S1b phase between 7.3 and $6.3 \mathrm{ka}$ (Fig. 3g). The transition between the Younger Dryas event and the Holocene is characterized by an abrupt $\delta^{18} \mathrm{O}_{\mathrm{w}}$ increase of $1.8 \%$. Then, from $\sim 11 \mathrm{ka}$ to $\sim 6.8 \mathrm{ka}$, the $\delta^{18} \mathrm{O}_{\mathrm{w}}$ compositions lie on a decreasing trend of some $1.9 \%$, suggesting a pronounced surface water salinity decrease. Smaller centennial fluctuations of about $0.7 \%$ and $1 \%$ are superimposed over the inferred main decreasing trend during the sapropel S1a and $\mathrm{S} 1$ interruption respectively (Fig. $3 \mathrm{~g}$ ). Moreover, the sapropel $\mathrm{S} 1 \mathrm{~b}$ is punctuated by high amplitude $\delta^{18} \mathrm{O}_{\mathrm{w}}$ short-term changes with a more saline phase between 8.1 and $7.8 \mathrm{ka}$ and at $\sim 7.5 \mathrm{ka}$ separated by a pronounced salinity decrease recorded at $\sim 7.7 \mathrm{ka}$. Finally, a large $\delta^{18} \mathrm{O}_{\mathrm{w}}$ drop (1\%o) occurred at the end of the sapropel S1b between 7.3 and $6.8 \mathrm{ka}$ separated by an abrupt short-term $\delta^{18} \mathrm{O}_{\mathrm{w}}$ increase at $7.1 \mathrm{ka}$. Therefore, the main salinity $\left(\delta^{18} \mathrm{O}_{\mathrm{w}}\right)$ decreases do not occur during the deposition of the sapropelic horizons but rather during the S1 interruption and the post-sapropel S1 deposition. We can thus infer that the whole salinity increase at the transition between the Younger Dryas and the Holocene is completely counterbalanced after the second phase of the sapropel S1.

A more pronounced increase in surface water $\delta^{18} \mathrm{O}_{\mathrm{w}}$ $(\sim 1 \%$ o $)$ was finally recorded from $\sim 6.9 \mathrm{ka}$, suggesting a progressive salinity rise before attaining mean presentday values at about $6.3 \mathrm{ka}$. However, it should be emphasized that, despite the salinity rise, short-term centennial- to 
millennial-scale $\delta^{18} \mathrm{O}_{\mathrm{w}}$ fluctuations distinguished the mid- to upper Holocene period (Fig. 3g).

\section{Discussion}

\subsection{Holocene hydrological changes in the SAS}

The stratigraphical record and SST estimates of the marine deep-sea core MD 90-917 have shown that the major climatic changes in this basin are in phase with the Greenland ice core record (Fig. 3a, b; Siani et al., 2001, 2010). This represents a solid starting point to provide new insight about the exact timing of the past hydrological evolution in the South Adriatic Sea, thus facilitating comparison with other climatic records at regional and global scale.

Our multi-proxy paleohydrological reconstructions have revealed two majors trends: an early to mid-Holocene pattern between $11.5 \mathrm{ka}$ and $6.3 \mathrm{ka}$ marked by a lowering of $\delta^{18} \mathrm{O}_{\mathrm{w}} /$ salinity and of the planktonic and benthic $\delta^{13} \mathrm{C}$ values followed by a shift toward higher values during the midto upper Holocene (Fig. 3e, f, g).

Superimposed on the general $\delta^{18} \mathrm{O}_{\mathrm{w}}$ and G. bulloides $\delta^{13} \mathrm{C}$ trends, short-term centennial- to millennial-scale fluctuations characterized the Holocene period in the SAS. It was also revealed that during the early to mid-Holocene South Adriatic SST changes match short-term $\delta^{18} \mathrm{O}_{\mathrm{w}}$ fluctuations. Conversely, since about $6 \mathrm{ka}$, SSTs display rather weak variability, whereas sea surface water proxies show higher amplitude oscillations, indicating a disconnection from temperature influence. Interestingly, most of the $\delta^{18} \mathrm{O}_{\mathrm{w}}$ /salinity lowering match well G. bulloides $\delta^{13} \mathrm{C}$ ones, suggesting a causal link between both records (Fig. 3f, g).

The G. bulloides $\delta^{13} \mathrm{C}$ record of Adriatic surface water could reflect a combination of global carbon budget changes, the degree of air-sea isotopic equilibration and regional changes in upwelling or in $\delta^{13} \mathrm{C}$ of its source waters (Pierre, 1999). The oligotrophic state of the Mediterranean Sea after the phase of the sapropel S1, and the absence of correspondence between temporal $\delta^{13} \mathrm{C}$ changes and the global rise of atmospheric $\mathrm{CO}_{2}$, allow us to relate lower $G$. bulloides $\delta^{13} \mathrm{C}$ values to the increasing input via the Po and/or coastal Italian, Apennine and Albanian rivers of remineralized continental organic matter presenting depleted $\delta^{13} \mathrm{C}$ values. In this regard, a recent survey of the carbon isotope composition of the planktonic foraminifera along the southern Italian coast of the Adriatic Sea pointed out a strong relationship between lower $\delta^{13} \mathrm{C}$ values and the increasing influence of less saline waters originated from the input of the Po River (Grauel and Bernasconi, 2010).

\subsubsection{Millennial-scale Holocene climatic variability}

During the early Holocene ( 11.5 to $9 \mathrm{ka}$ ) the $\delta^{18} \mathrm{O}_{\mathrm{w}}$ record from core MD90-917 indicates significant millennial-scale hydrological changes in accordance with previous recon-

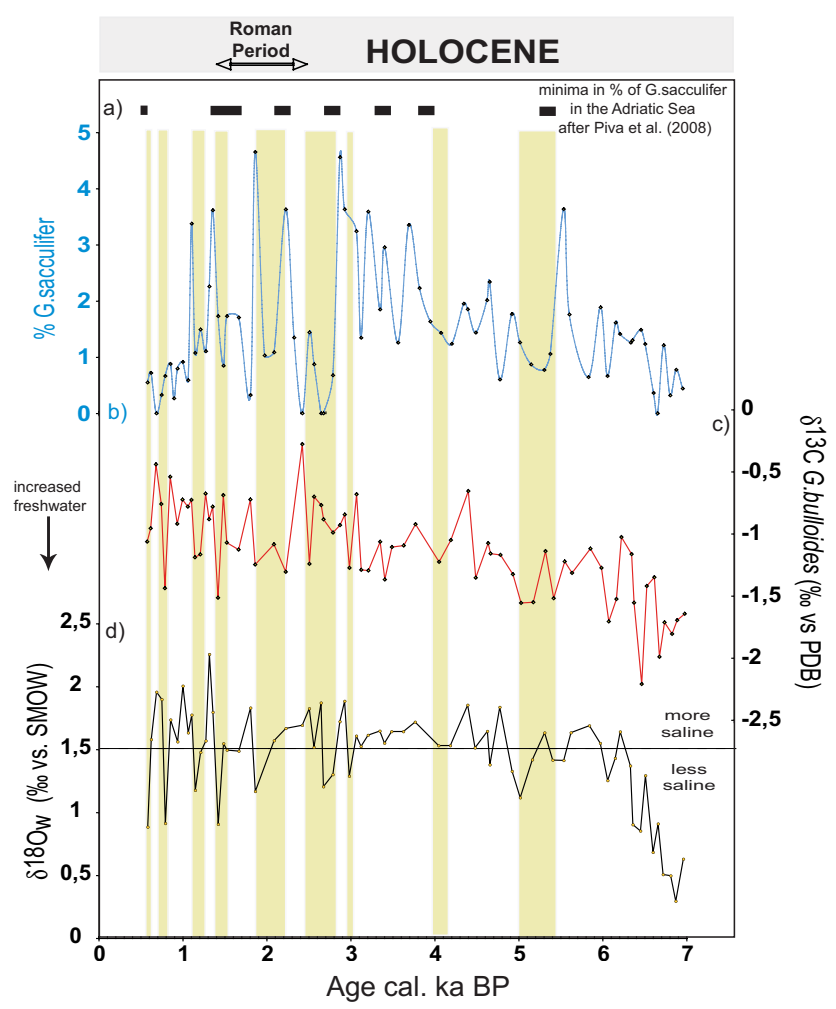

Fig. 5. Comparison of the surface dwelling foraminifera Globigerinoides sacculifer abundance and hydrological changes in core MD90-917 vs. age (cal.kaBP). (a) G. sacculifer minima events recorded in the Adriatic Sea (Piva et al., 2008). (b) Percentage of $G$. sacculifer in core MD90-917. (c) $\delta^{13} \mathrm{C}$ of the planktonic foraminifera G. bulloides. (d) Sea water $\delta^{18} \mathrm{O}$ record $\left(\delta^{18} \mathrm{O}_{\mathrm{w}}\right)$. Yellow bars indicate $\delta^{18} \mathrm{O}_{\mathrm{w}}$ /salinity and G. bulloides $\delta^{13} \mathrm{C}$ minima.

structions in the Tyrrhenian and Aegean seas, in the Strait of Sicily and in the Levantine Basin (Kallel et al., 1997a; Emeis et al., 2000; Essellami et al., 2007; Marino et al., 2009). This is in turn confirmed by the planktonic foraminifera $\delta^{18} \mathrm{O}$ records displaying a trend identical to the SAS one with a similar negative $\sim 2 \%$ o shift during the same time interval (Fig. 3c). This suggests that these basins were influenced by similar climatic conditions, and the salinity lowering of the surface waters had probably a common origin. Such hydrological changes occurred during the intensification of the orbitally forced African monsoon activity establishing the onset of humid conditions in the eastern Mediterranean Basin (Rossignol-Strick et al., 1982; Richie et al., 1985). This induced an intensified flooding of the Nile and small African tributary rivers and the resulting input of isotopically light freshwater, weakening the Mediterranean thermohaline circulation and leading to the sapropel S1 formation (RossignolStrick et al., 1982; Fontugne et al., 1994; Rohling, 1994; Kallel et al., 1997b; Emeis et al., 2000; Scrivner et al., 2004). The large drop in salinities at the beginning of the Holocene and during the sapropel S1 was observed during increased 
pluvial conditions in the South Adriatic Sea (CombourieuNebout et al., 1998) coeval to a period of enhanced rainfall in the eastern Mediterranean region (Bar-Matthews et al., 2000). Likewise, Kallel et al. (1997b) showed that sea surface salinity during the sapropel S1 was lower than today and almost homogeneous in the whole Mediterranean Sea according to marked pluvial conditions that equilibrated the negative freshwater budget.

During the early to mid-Holocene (9 to $6.3 \mathrm{ka}$ ), the emerging hydrological pattern observed in the South Adriatic record presents a feature similar to that documented in the Aegean Sea (Rohling et al., 2002; Marino et al., 2009). The strong resemblance between both climatic records, as also pointed out by similar $\delta^{18} \mathrm{O}_{\mathrm{w}}$ amplitude changes, emphasizes a broad climatic link between these basins (Fig. 4). Interestingly, the post-sapropel S1 SST cooling recorded in the Aegean Sea is coeval, within chronological $1 \sigma$ uncertainties, to the SAS one dated between 7.3 and $6.3 \mathrm{ka}$ (Fig. 4c, d; Marino et al., 2009). Such cooling has been related to a long-term (multi-decadal) period of severe winter outbreaks of cold and dry northeast winds (Rohling et al., 2002). Therefore, we argue that these cooling events may have induced the resumption of deep-water formation after the sapropel S1b both in the Adriatic and Aegean seas. Indeed, density of the surficial waters was sufficiently high during the post-sapropel termination to enable the ventilation of the deep Adriatic Basin, due to the counterbalance between salinity depletion and SST decrease. This scenario is also confirmed by higher benthic $\delta^{13} \mathrm{C}$ values $(\sim 1.1 \%$ ) recorded between 7.3 and $6.3 \mathrm{ka}$, attesting to a resumption of the Adriatic deep-sea water formation just after the sapropel S1b phase (Fig. 3e). Such a feature is corroborated by a significant increase in the abundance of the benthic foraminifera Cibicidoides observed in the Aegean Sea (Kuhnt et al., 2007; Abu-Zhied et al., 2008) and in the South Adriatic (Jorissen et al., 1993) indicating the return to full oxic conditions.

The increased precipitation during the sapropel S1 event does not necessarily represent the sole condition which released a drop in sea surface salinity favoring deep water stagnation. Indeed, the global climatic pattern observed at the time of sapropel S6 formation coincided with an arid climate phase as indicated by the reduction of Mediterranean evergreen vegetation and by the pollen sequence of Quercus (Cheddadi and Rossignol Strick, 1995). This large drop in salinities, observed during the sapropel S1, was also synchronous to the Holocene sea-level rise by $\sim 35 \mathrm{~m}$ in the ocean (Lambeck and Chappell, 2001), and persisted until the second SST cooling observed between 7.3 and $6.3 \mathrm{ka}$ while the melting of the global ice sheets was largely complete The sea level rise was probably the sole short event which could have influenced the oceanic circulation in the Mediterranean Sea at the time of sapropel S1. In the Adriatic Sea a sea level rise of $\sim 35 \mathrm{~m}$ probably induced a seawater transgression, flooding the ancient coastlines. Such a transgression gave rise to erosional and depositional processes, increasing markedly the feeding of continental organic matter in the seawater during the sapropel S1. This hypothesis agrees with data proposed by Fontugne et al. (1989) on the origin of the organic matter in the Adriatic Sea during the sapropel S1 deposition.

The large $G$. bulloides $\delta^{13} \mathrm{C}$ drop by about $1 \%$ between 9.1 and $6.3 \mathrm{ka}$ indicates prominent sea surface water $\delta^{13} \mathrm{C} \mathrm{de}$ pletion during and after the sapropel S1 period (Fig. $3 \mathrm{f}$ ). The low $\delta^{13} \mathrm{C}$ values of surface $\mathrm{CO}_{2}$ might be resulted from the remineralization of continental organic matter that presents depleted $\delta^{13} \mathrm{C}$ values. Fontugne and Calvert (1992) proposed that markedly low $\delta^{13} \mathrm{C}$ values of the planktonic foraminifera Globigerinoides ruber in the sapropels probably reflect the shift in isotopic composition of dissolved inorganic carbon due to the mixing of freshwater. The sapropel S1 $\delta^{13} \mathrm{C}$ depletion could also indicate a decrease of the level of photosynthesis, as generally it extracts light $\mathrm{CO}_{2}$ from surface waters and leads to increased ${ }^{13} \mathrm{C}$ content (Shackleton et al., 1983).

The following mid- to upper Holocene period is characterized by a $\delta^{18} \mathrm{O}_{\mathrm{w}} /$ salinity increase since $\sim 6 \mathrm{ka}$, attesting to an aridification phase in the South Adriatic Sea coeval to the end of the postglacial sea level rise (Fig. 3g). This interval is accompanied by the complete resumption of deep convection in the Adriatic Sea since $6 \mathrm{ka}$ as indicated by higher $C$. pachydermus $\delta^{13} \mathrm{C}$ values $(\sim 1.3 \%$ ) similar to the modern ones (Fig. 3e). This result is in agreement with the last occurrence in the subsurface water masses of the planktonic foraminifera Globorotalia inflata that marks the onset of the modern circulation regime distinguished by changes in Adriatic water column structure becoming more oligotrophic at surface as today (Siani et al., 2010).

\subsubsection{Centennial-scale Holocene climate variability}

The SAS hydrological record from core MD90-917 also illustrates Holocene short-term centennial climatic variability. During the early to mid-Holocene, a short-term SST and $\delta^{18} \mathrm{O}_{\mathrm{w}}$ /salinity decrease was observed during the $\mathrm{S} 1$ interruption, coeval to the $\delta^{18} \mathrm{O}$ minimum recorded in Greenland ice cores and in lacustrine series at $8.2 \mathrm{ka}$ (Fig. 3b, g; Johnsen et al., 1992; von Grafenstein et al., 1998). During the S1 interruption, density of the surficial waters was sufficiently high to permit ventilation of the deep Adriatic Basin, due to the counterbalance between salinity depletion and SST decrease. However, the benthic $\delta^{13} \mathrm{C}$ record in core MD90-917 indicates lower values compared to modern ones during the S1 interruption (between 0.9 to $0.2 \%$ ), probably due to a mixture between the stagnant and old carbon depleted deepwater masses at the time of the sapropel S1 and those of the "new" formation (Fig. 3e). Resumption of a major deepwater convection during this short event is also distinguished by the re-occurrence of benthic oxygen supply foraminifera in the SAS (Jorissen et al., 1993; Rohling et al., 1997).

The most striking feature that punctuated the mid- to upper Holocene in the SAS is the occurrence of short-lived low $\delta^{18} \mathrm{O}_{\mathrm{w}}$ /salinity events that peaked at around 5-4.8, 3-2.7, 
2-1.8, 1.4, 1.2 and $0.8-0.6 \mathrm{ka}$ (Fig. 3g). As already discussed above, most of the $\delta^{18} \mathrm{O}_{\mathrm{w}}$ /salinity short-term lowering correspond to the drop in G. bulloides $\delta^{13} \mathrm{C}$ values and do not reflect primarily temperature changes as displayed by the SST record. Therefore, these short $\delta^{13} \mathrm{C}$ spells should rather be related to lower salinity events. Such negative salinity anomalies may be attributed either to an enhanced river flooding from the Po, Apennine and Albanian rivers or to reduced Levantine Intermediate Waters intrusion in the SAS.

To verify the hypothesis of a plausible influence of enhanced riverine freshwater, we considered the abundance distribution of the oligotrophic, shallow water dweller planktonic foraminifera Globigerinoids sacculifer in core MD90917 (Fig. 5). According to the micropaleontological study of Piva et al. (2008) carried out on several cores in the Adriatic Sea, the frequency peaks of $G$. sacculifer were interpreted in terms of hydrological optimum conditions characterized by low turbidity of the water column and reduced river runoff. Conversely, the drop in G. sacculifer concentration was related to short-lived phases of cool and rainy events and increased river runoff (Piva et al., 2008).

Interestingly, over the last $6 \mathrm{ka}$ the main frequency of $G$. sacculifer minima previously recorded in the southern and central Adriatic at around 1.4, 2.2, 3.2-2.7, 3.8 and $5 \mathrm{ka}$ (Piva et al., 2008) are coeval, within chronological $1 \sigma$ uncertainties, with the G. sacculifer minima events recorded in core MD90-917 (Fig. 5a, b). In addition, with the exception of the event dated at $2.9 \mathrm{ka}$, the short-lived phases of $\delta^{18} \mathrm{O}_{\mathrm{w}} /$ salinity and $G$. bulloides $\delta^{13} \mathrm{C}$ match well changes of $G$. sacculifer distribution in core MD90-917 (Fig. 5c, d). This provides additional constrains for an increased riverine discharge most likely from the Po River around the semi-enclosed Adriatic Basin. However, we cannot discard the influence of distinct inputs from several Apennine rivers (Frignani et al., 2005; Palinkas and Nittrouer, 2006).

A further valuable support to our interpretation is based on sedimentological and micropaleontological studies carried out on marginal Adriatic marine deposits to reconstruct the depositional evolution of the Po River delta (Correggiari et al., 2005; Stefani and Vincenzi, 2005; Amorosi et al., 2008; Rossi and Vaiani, 2008). These studies have shown evidence of increased Po River discharge events, which took place after the maximum marine transgression dated at $\sim 5.5 \mathrm{ka}$. Accordingly, the temporary increase of Po River discharge at $4.7 \pm 0.15 \mathrm{ka}$ (Rossi and Vaiani, 2008) is coeval, within chronological $1 \sigma$ uncertainties, to the G. bulloides $\delta^{13} \mathrm{C}$ and $\delta^{18} \mathrm{O}_{\mathrm{w}}$ minima event dated in core MD90-917 between 5 and $4.8 \mathrm{ka}$. Similarly, the occurrence of several generation of cuspate delta developed across the Po Plain between 3 to $0.9 \mathrm{ka}$ have also been related to an increasing sediment supply triggered both by the clearing of forest in the watershed and by increased precipitation and/or meltwater (Correggiari et al., 2005; Stefani andVincenzi, 2005).
Interestingly, most of the $\delta^{18} \mathrm{O}_{\mathrm{w}}$ and $\delta^{13} \mathrm{C}$ minima events recorded in core MD90-917 fall within the same time interval (Figs. 3, 5).

The centennial-scale SAS hydrological events also correspond to the wet-dry-wet cycle reconstructed in the central Mediterranean during the Roman Period (RP) between ca. 2.6 and $1.6 \mathrm{ka}$ (Dermody et al., 2012). These events, mainly related to the position and intensity of the jet streams, have been correlated to millennial changes in North Atlantic oscillation mode (Chen et al., 2011; Dermody et al., 2012).

An alternative hypothesis to decipher these short-term events could relate to the balance between the strengthening or weakening in the rate of LIW formation and its intrusion in the South Adriatic Sea. A slowdown of the LIW formation in the Levantine Basin marked by a pronounced salinity lowering was observed at ca. $3 \mathrm{ka}$ (Emeis et al., 2000). This event could correspond to the $\delta^{18} \mathrm{Ow} / \mathrm{salinity}$ minima event and be the coeval short-term C. pachydermus $\delta^{13} \mathrm{C}$ decrease centered at around $2.9 \mathrm{ka}$ in the SAS (Fig. 3e, g).

The inferred short-term hydrological changes, even of lesser amplitude compared to the early to mid-Holocene period, might have precluded the formation of deep bottom waters in the South Adriatic Sea. In fact, it is well known that the formation of deep Adriatic bottom waters is very sensitive to small increases in water temperature $\left(0.7^{\circ} \mathrm{C}\right)$ or small decreases in salinity $(0.2$ per mil) promoting stratification of water masses (Mangini and Sclosser, 1986). Striking evidence was observed for 2 to $0.8 \mathrm{ka}$, where the centennialscale $\delta^{18} \mathrm{O}_{\mathrm{w}}$ and $\delta^{13} \mathrm{C}$ minima events correspond to the lack of oxic benthic foraminifera in core MD90-917, suggesting a period during which the formation of deep bottom waters in the South Adriatic Sea was probably more reduced than today.

\subsection{Holocene land-sea climatic comparison}

To decipher possible land-sea relationships as suggested by the examination of the isotope records from core MD90-917 in the preceding discussion, Fig. 6 presents comparisons of the sea surface $\delta^{18} \mathrm{O}_{\mathrm{w}} /$ salinity record of core MD90-917 with paleohydrological records established in the central Mediterranean area and north of the Alps in west-central Europe. The data collected in the central Mediterranean are based on (1) pollen-inferred quantitative estimates of annual precipitation (PANN) in Pergusa (Sadori and Narcisi, 2001; Magny et al., 2012a), (2) glacier advances and alluvial events in the Gran Sasso Massif in central Italy (Giraudi, 2005a, b), (3) paleohydrological variations reconstructed in southern and central Italy (Giraudi et al., 2011) from various proxies, and (4) the lake-level records from Lake Accesa in central Italy (Magny et al., 2007, 2012b). The data collected north of the Alps in west-central Europe are based on (1) a lake-level record reconstructed at Lake Cerin in the Jura Mountains (Magny et al., 2011a) and a regional lake-level record established for west-central Europe (Magny, 2004, 


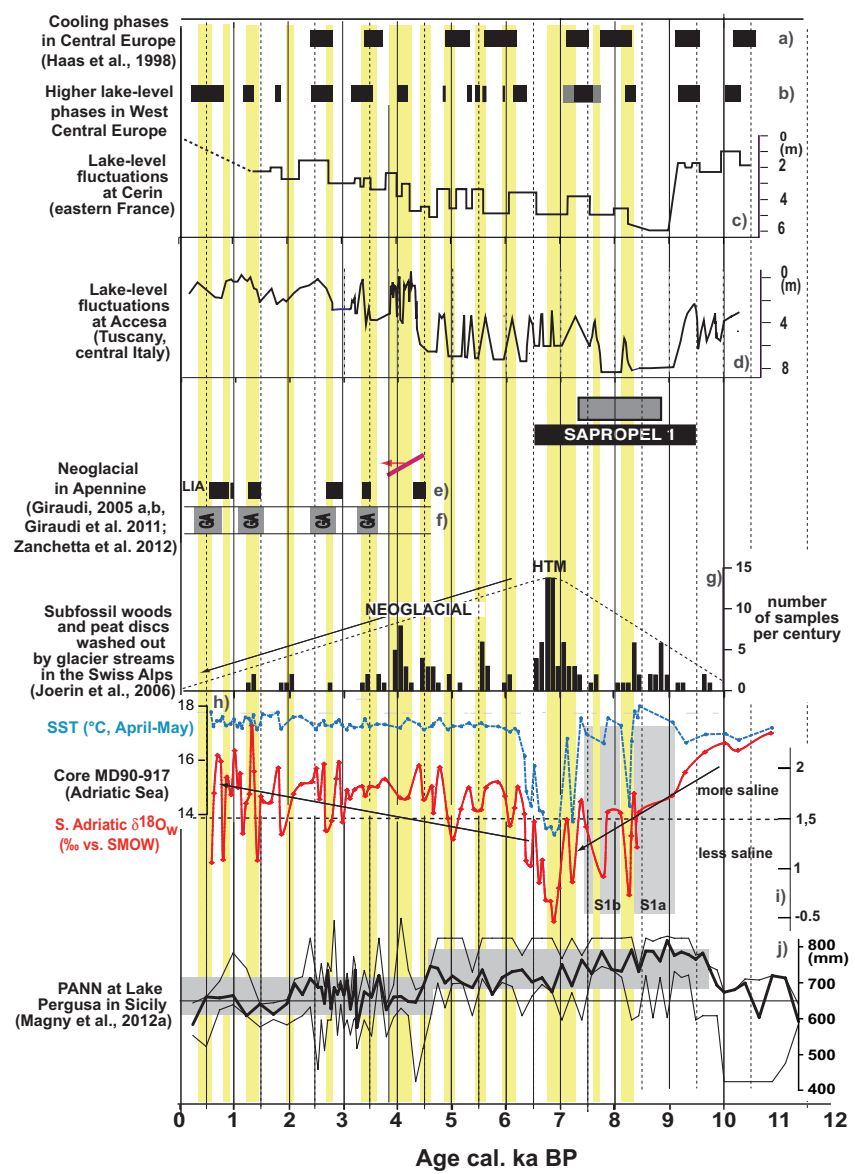

Fig. 6. Comparison between the hydrological record from core MD90-917 (this study) and continental climate proxies: (a) central Europe cooling events reconstructed from various proxies in the Swiss Plateau and Alps (Haas et al., 1998). (b) Phases of higher lake level in west-central Europe (Magny, 2004, 2006). (c) Lakelevel record of Cerin (Magny et al., 2011a); (d) lake-level record of Accesa (Magny et al., 2007). (e) Phases of cooler/wetter climatic conditions reconstructed in southern and central Italy (Giraudi et al., 2011; Zanchetta et al., 2012); LIA = Little Ice Age; red arrow corresponds to the onset of the Neoglacial period. (f) Glacial advances in the Gran Sasso Massif, central Italy (Giraudi 2005a, b); $\mathrm{GA}=$ glacier advance. (g) Frequency of subfossil woods and peat discs in proglacial fluvial sediments in the Swiss Alps (Joerin et al., 2006). (h) South Adriatic Sea surface temperature (this study). (i) South Adriatic $\delta^{18} \mathrm{O}_{\mathrm{w}}$ record (this study). (j) Pollen-inferred quantitative estimates of annual precipitation at Pergusa, central Sicily (Magny et al., 2012a). S1a and S1b refer to the two-step sapropel $\mathrm{S} 1$ units in the SAS. The yellow lines indicate low $\delta^{18} \mathrm{O}_{\mathrm{w}} /$ salinity values in core MD90-917.

2006), (2) cooling events identified from various proxies in the Swiss Plateau and Alps (Haas et al., 1998), and (3) glacier variations reconstructed in the Swiss Alps from radiocarbondated subfossil woods and peat discs washed out by glacier streams (Joerin et al., 2006).
At a pluri-millennial scale, the general trends shown by the sea surface salinity record from core MD90-917 appear to be in general agreement with the PANN record of Pergusa (Fig. 6j; Magny et al., 2012a). The maximum of precipitation observed in central Sicily around 9.5 to $7 \mathrm{ka}$ is consistent with lower salinity values in the SAS during the early to midHolocene. In contrast, the aridification trend suggested by higher salinity values during the second half of the Holocene corresponds to a general decrease in PANN at Pergusa after 7 to $6.5 \mathrm{ka}$. Considered as a whole, the mid-Holocene phase of salinity minimum in the SAS appears to be also consistent with a maximum of humidity in the winter season in the north-central Mediterranean suggested by minimum values in the oxygen isotope record from Corchia cave (Zanchetta et al., 2007) and pollen-inferred maximum of winter precipitation at Lake Accesa (Peyron et al., 2011; Magny et al., 2012a).

At a centennial scale, during the second half of the Holocene, Fig. 6 shows possible synchronicities (within the radiocarbon-dating uncertainty) between phases of lower salinity in the SAS and periods of wetter climatic conditions around the north-central Adriatic Sea, marked by glacial advances in the Gran Sasso Massif and lake-level changes at Lakes Accesa. However, the SAS salinity record does not display any strong signature in correspondence with the initiation of the Neoglacial period dated to ca. $4.5-4 \mathrm{ka}$ in the north-central Mediterranean (Zanchetta et al., 2012) and well marked by an abrupt rise in lake level at lakes Accesa (Fig. 6d) and Ledro (Magny et al., 2007, 2012b). At more southern latitudes in the central Mediterranean, the strong temperature decreases in the MD90-917 SST record around 8.2 and 7.3 to $6.3 \mathrm{ka}$ coincided with drier climatic conditions around 8.4 to 8.2 and $7.4 \mathrm{ka}$ at Lake Preola in Sicily, with a maximal lowering around $7.3 \mathrm{ka}$ and resuming eolian deposition (Magny et al., 2011b). Stable isotope data from a cave in northern Sicily indicate two successive cold and dry events that interrupted the wet mid-Holocene at ca. 8.2 and $7.5 \mathrm{ka}$ (Frisia et al., 2006). Stable-isotope and pollen records from the northern Aegean Sea have also given evidence of cold and dry intervals marked by drops of deciduous tree pollen at around 8.3-8, 7.5-6.3 and 4.4-4 ka (Kotthoff et al., 2008a, b; Schmiedl et al., 2010). A similar decrease in arboreal vegetation has been observed during the period immediately after the sapropel 1 deposition in core MD90-917 (CombourieuNebout et al., 1998).

Figure 6 gives evidence of other possible correlations between short-lived phases of cooler/wetter climatic conditions north of the Alps and centennial-scale phases of lower salinity in the SAS. Regarding the region north of the Alps, Fig. 6 also presents striking similarities at a centennial scale between phases of lower salinity in the SAS and those of higher frequency of subfossil woods recognized in proglacial fluvial sediments in the Swiss Alps (Joerin et al., 2006). According to these authors, the peaking frequency of subfossil remains of wood and peat discs dated to the mid-Holocene reflects an 
elevation maximum of the Alpine timberline favored by the Holocene Thermal Maximum. At a centennial scale, these authors also interpret the successive peaks of subfossil woods as glacier recessions favoring forest expansions. However, the significance of peaks of subfossil woods and peat discs reconstructed by Joerin et al. (2006) may be not straightforward. Considering their timing, they also could correspond, at least partly, to phases of glacier advances and increasing runoff responsible for forest destruction in high-elevated areas and for accumulation of remains of woods and peat in proglacial fluvial sediments downstream of glacier tongues, as suggested for instance by a peak of subfossil woods contemporaneous with an advance of the Aletsch Glacier around $1.3 \mathrm{ka}$ (Joerin et al., 2006; Holzhauser et al., 2005). Such an alternative interpretation is also supported by apparent synchronicities between peaks of subfossil woods in the Swiss Alps and cooler/wetter phases marked north of the Alps by higher lake levels (Magny, 2006) as well as in Alpine and central European paleoclimatic series, e.g. glaciers, treelines, and chironomids (Haas et al., 1998; Heiri et al., 2004). Thus, the period around the $8.2 \mathrm{ka}$ event corresponds to an interruption of S1 deposition, higher lake levels in central and northern Italy, a cooling event (Haas et al., 1998) and a peak of subfossil woods (Joerin et al., 2006) in the Swiss Alps. A similar observation may be developed for the cooling period between 7.3 and $6.3 \mathrm{ka}$ marked by a minimum in salinity and SST in the SAS. The Holocene glacier history reconstructed by Luetscher et al. (2011) from Alpine speleothems in Switzerland shows that the Upper Grindelwald Glacier readvanced from ca. 7.2 to $6.8 \mathrm{ka}$. As discussed by Magny et al. (2011a, 2012b), imprints of a climatic reversal at ca. 7.5 to $7 \mathrm{ka}$ may be found also in Mediterranean paleoclimatic records from lakes Medina in southern Spain (Reed et al., 2001), Xinias in Greece (Digerfeldt et al., 2007), and Gölhisar in southwestern Turkey (Eastwood et al., 2007). Moreover, its range may have exceeded the European continent as suggested by a near cessation of the early to midHolocene sea level rise (Bird et al., 2010), as well as by a major IRD peak in the North Atlantic (Bond et al., 2001) and an expansion of polar water in the Nordic seas (Rasmussen and Thomsen, 2010). The interval at 8 to $7 \mathrm{ka}$ also appears to be synchronous with the highest rate of change in annual insolation for the Holocene (Zhao et al., 2010).

\subsection{Frequency of the Holocene climatic variability in the SAS}

In order to shed light on the origin of the Holocene climate variability in the central Mediterranean area, we have used wavelet analysis of the SAS hydrological record. During the early to mid-Holocene between ca. 10 and $6 \mathrm{ka}$, wavelet analysis on the $\delta^{18} \mathrm{O}_{\mathrm{w}}$ record show two main frequency patterns: one at $\sim 1280$ and one at $735 \mathrm{yr}$ (Fig. 7). After 6 ka only the wavelet analysis on the G. bulloides $\delta^{13} \mathrm{C}$ record defines a frequency at $\sim 1670 \mathrm{yr}$. These results clearly show that both

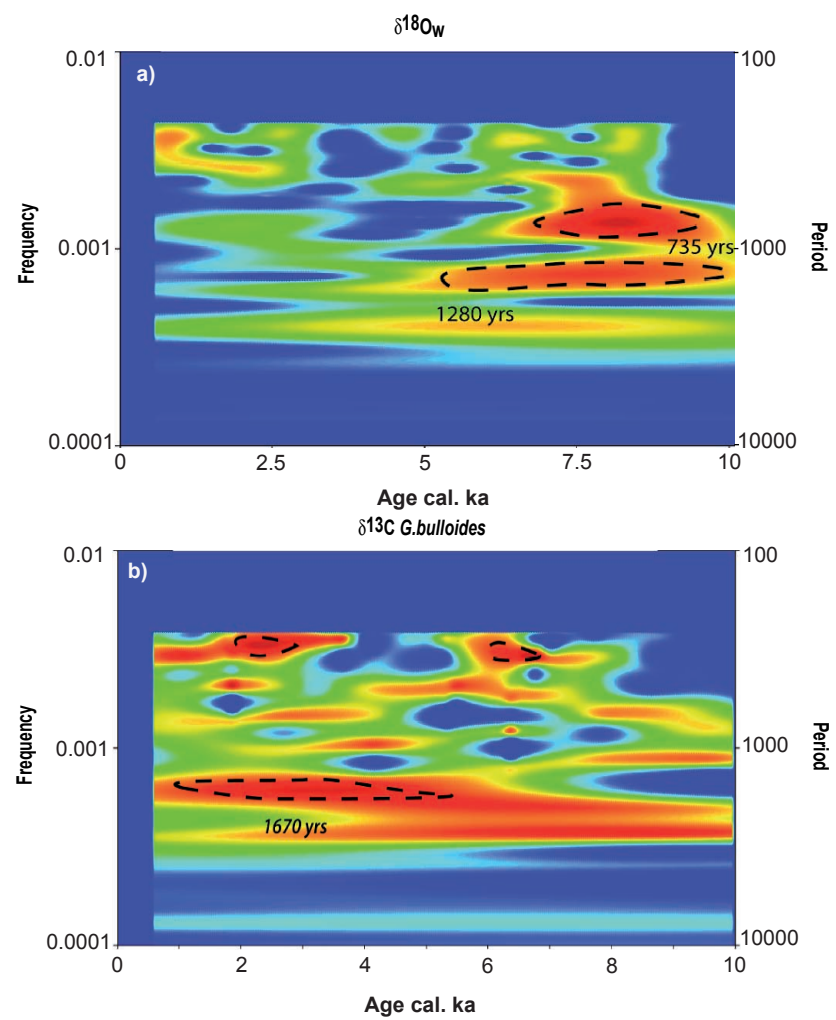

Fig. 7. Wavelet spectrum of the MD90-917 marine hydrological record for (a) $\delta^{18} \mathrm{O}_{\mathrm{w}}$ /salinity and (b) $\delta^{13} \mathrm{C}$ Globigerina bulloides. The $95 \%$ confidence level is indicated by a dashed line.

$\delta^{18} \mathrm{O}_{\mathrm{w}}$ and $\delta^{13} \mathrm{C}$ signals are structured by different millennial frequency patterns. The $\delta^{18} \mathrm{O}_{\mathrm{w}}$ record displays frequencies present exclusively during the early to mid-Holocene, whereas the $\delta^{13} \mathrm{C}$ record suggests an inverse pattern with a significant millennial-scale frequency between 6 and $0.6 \mathrm{ka}$. Consequently, these two signals are not related to the same forcing in terms of millennial-scale climate changes.

The early to mid-Holocene $\delta^{18} \mathrm{O}_{\mathrm{w}}$ frequencies are not typical of a well-known spectral imprint (Debret et al., 2009). However, these frequencies indicate that the signal is structured, suggesting that $\delta^{18} \mathrm{O}_{\mathrm{w}}$ records significant variations related to climate or environmental changes. Conversely, the $\delta^{18} \mathrm{O}_{\mathrm{w}}$ wavelet analysis does not allow identification of a periodic behavior of the climate at centennial and millennial scales after $6 \mathrm{ka}$. It is likely that during the Holocene the $\delta^{18} \mathrm{O}_{\mathrm{w}}$ signal was disturbed by local precipitation, runoff, melt water flux and evaporation changes produced in the semi-enclosed South Adriatic Basin that could have hidden the most meaningful frequencies.

Regarding the $\delta^{13} \mathrm{C}$ signal, it shows a frequency after $6 \mathrm{ka}$ with a period at $\sim 1670 \mathrm{yr}$. A comparable frequency can be reported for an internal forcing probably attributed to oceanatmosphere coupling (Debret et al, 2007, 2009; Hoogakker et al., 2011). A similar spectral signal was also identified in the oxygen isotopic record from a speleothem in southwestern 


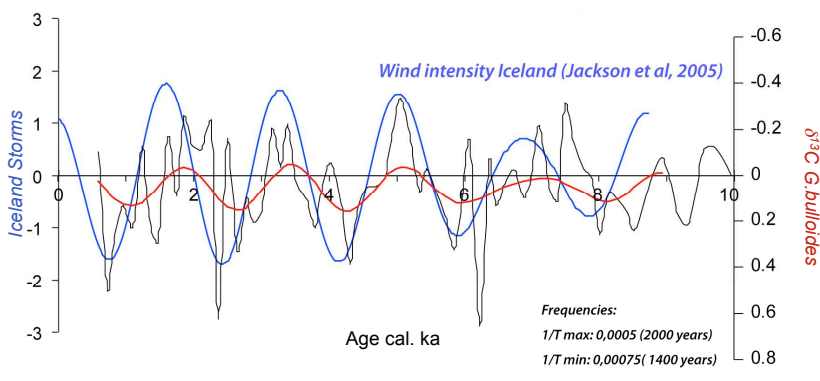

Fig. 8. Comparison of millennial-scale evolution of the 1670-yr cycles between storm episodes in Iceland (blue line; Jackson et al., 2005) and the G. bulloides $\delta^{13} \mathrm{C}$ record in the South Adriatic Sea, showing the raw data (black line) and low-frequency band pass (red line).

Ireland (McDermott et al., 2001; Debret et al., 2007), suggesting a strong link between North Atlantic climate and ice core temperature. Interestingly, by comparing the SAS $\delta^{13} \mathrm{C}$ frequency with that obtained from an Icelandic loessic sequence representative of stormy episodes in North Atlantic we find an imprint similar and coeval to that identified by Jackson et al. (2005; Fig. 8). This implies that the identification of this frequency in the $\delta^{13} \mathrm{C}$ signal may indicate a common link between the central Mediterranean and North Atlantic area during the mid- to upper Holocene and consequently strengthens the relationship between $\delta^{13} \mathrm{C}$ and freshwater coming from the Po River. Today, the Po River runoff is closely linked to the negative North Atlantic oscillation (NAO) index exercising a strong influence on the winter precipitation pattern over Europe on an interannual to decadal timescale (Zanchettin et al., 2008). In addition, both Adriatic and north Atlantic records present a coeval mid-Holocene transition corresponding to a Holocene worldwide pattern (Debret et al., 2009), in agreement with the initiation of the Neoglacial period in the north-central Mediterranean (Zanchetta et al., 2012). This major outcome assesses the origin of the forcing factors leading to these short-term climatic changes during the Holocene in the SAS, even though the mechanisms responsible for millennial-scale climate variability still remain not completely understood.

\section{Conclusions}

The multi-proxy hydrological record from the SAS has provided new clues on the Holocene climate changes produced in the central Mediterranean area. These reconstructions have revealed two major hydrological trends confirming the presence of a strong climatic mid-Holocene transition in the South Adriatic Sea:

1. an early to mid-Holocene pattern between $11.5 \mathrm{ka}$ and $6.3 \mathrm{ka}$ marked by sea surface salinity lowering and reduced deep-sea convection mainly centered during the sapropel S1 phase (9.3 to $7.4 \mathrm{ka}$ ) followed by a shift toward

2. more saline waters and arid conditions during the midto upper Holocene, attesting to the resumption of the Adriatic deep water formation since about $6.3 \mathrm{ka}$.

However, beyond the two main paleohydrological transitions, short-term centennial-scale hydrological changes have distinguished the entire Holocene. During the sapropel S1, despite the surface salinity lowering, short-term SST cooling spells are responsible for the resumption of deep-water formation and re-oxygenation phases in the South Adriatic Basin during the $\mathrm{S} 1$ interruption. During the midHolocene, a significant SST cooling together with a prominent $\delta^{18} \mathrm{O}_{\mathrm{w}} /$ salinity lowering ( $1 \%$ o ) were recorded at the end of the sapropel $\mathrm{S} 1 \mathrm{~b}$ between 7.3 and $6.8 \mathrm{ka}$ separated by an abrupt short-term $\delta^{18} \mathrm{O}_{\mathrm{w}}$ increase at $7.1 \mathrm{ka}$.

Conversely, since about $6 \mathrm{ka}$, SST reconstructions have indicated rather weak variability, whereas $\delta^{18} \mathrm{O}_{\mathrm{w}}$ and G. bulloides $\delta^{13} \mathrm{C}$ values show short-term oscillations, suggesting a disconnection from temperature influence. Such centennialscale changes, mainly centered between 3 and $0.6 \mathrm{ka}$, have been attributed to a major influence of freshwater from the Po River even though a possible influence of coastal Italian, Apennine and Albanian rivers cannot be discarded. These short-term hydrological changes, even of lesser amplitude compared to the early to mid-Holocene period, could have affected the sea surface hydrology and consequently reduced the formation of deep bottom waters in the SAS affecting the thermohaline circulation in the Mediterranean Sea.

The high time resolution SAS Holocene hydrological record has also enabled the carrying out of comparisons with previous paleohydrological records from the central Mediterranean area and north of the Alps in west-central Europe. Taken as a whole and beyond the uncertainties due to the age models of the different archives, these climatic oscillations revealed a possible link between phases of lower salinity in the SAS and periods of wetter climatic conditions around the north and south-central Mediterranean area.

Finally, the mid- to upper Holocene episodes marked by lower $\delta^{13} \mathrm{C}$ values and salinities and attributed to an increased supply of freshwater from the Po River have displayed a periodicity of $\sim 1670 \mathrm{yr}$, reflecting the appearance after $6 \mathrm{ka}$ of a millennial oscillation driven by an oceanatmosphere forcing mainly centered in the North Atlantic region. These findings suggest significant coupling between high-latitude North Atlantic climate and the South Adriatic hydrologic cycle. 
Acknowledgements. This study was supported by the French ANR (project LAMA, M. Magny and N. Combourieu Nebout). Fabien Dewilde (LSCE) is gratefully acknowledged for the preparation of samples and assistance during isotope analyses. We also thank Nejib Kallel and Elisabeth Michel for useful discussions and two anonymous reviewers for their constructive suggestions.

Edited by: N. Combourieu Nebout

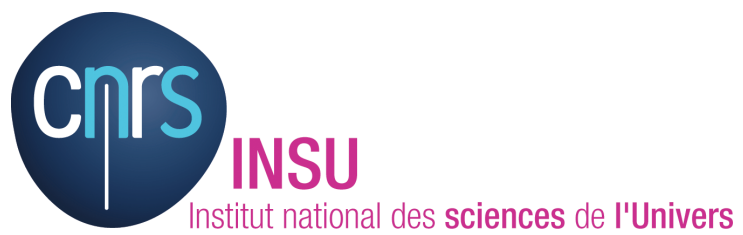

The publication of this article is financed by CNRS-INSU.

\section{References}

Abu-Zied, R., Rohling, E. J., Jorissen, F. J., Fontanier, C., Casford, J. S. L., and Cooke, S.: Benthic foraminiferal response to changes in bottom-water oxygenation and organic carbon flux in the eastern Mediterranean during LGM to Recent times, Mar. Micropal., 67, 46-68, 2008.

Amorosi, A., Dinelli, E., Rossi, V., Vaiani, S. C., and Sacchetto, M.: Late Quaternary palaeoenvironmental evolution of the Adriatic coastal plain and the onset of Po River Delta, Palaeogeogr. Palaeocl., 268, 80-90, 2008.

Artegiani, A., Azzolini, R., and Salusti, E.: On the dense water in the Adriatic Sea, Ocean. Acta, 12, 151-160, 1989.

Artegiani, A., Bregant, D., Paschini, E., Pinardi, N., Raicich, F., and Russo, A.: The Adriatic Sea general circulation: Part I. Air - sea interaction and water mass structure, Part II. Baroclinic circulation structure, J. Phys. Ocean., 27, 1492-1532, 1997.

Asioli, A., Trincardi, F., Lowe, J. J., Ariztegui, D., Langone, L., and Oldfield, F.: Sub-millennial scale climatic oscillations in the central Adriatic during the Lateglacial: palaeoceanographic implications, Quaternary Sci. Rev., 20, 1201-1221, 2001.

Bar-Matthews, M., Ayalon, A., and Kaufman, A.: Timing and hydrological conditions of Sapropel events in the Eastern Mediterranean, as evident from speleothems, Soreq cave, Israel, Chem. Geol., 169, 145-156, 2000.

Bird, M., Austin, W. E. N., Wurster, C. M., Fifield, L. K., Mojtahid, M., and Sargeant, C.: Punctuated eustatic sea-level rise in the eraly mid-Holocene, Geology, 38, 803-806, 2010.

Blanc, P. L. and Duplessy, J. C.: The deep-water circulation during the Neogene and the impact of the Messinian salinity crisis, Deep Sea Res. Part A. Ocean. Res. Papers, 29, 1391-1414, 1982.

Bond, G., Kromer, B., Beer, J., Muscheler, R., Evans, M. N., Showers, W., Hoffmann, S., Lotti-Bond, R., Hajdas, I., and Bonani, G.: Persistent solar influence on North Atlantic climate during the Holocene, Science, 294, 2130-2136, 2001.

Bottema, S. and Van Straaten, L. M. J. U.: Malacology and palynology of two cores from the Adriatic Sea floor, Mar. Geol., 4, 553-564, 1966.

Charbit, S., Rabouille, C., and Siani, G.: Effects of benthic transport processes on abrupt climatic changes recorded in deep-sea sed- iments: A time-dependent modeling approach, J. Geophys. Re., 107, 3149, doi:10.1029/2000JC000575, 2002.

Chedaddi, R. and Rossignol Strick, M.: Eastern Mediterranean Quaternary paleoclimates from pollen and isotope records of marine cores in the Nile cone area, Paleoceanography, 10, 291-300, 1995.

Cheddadi, R., Yu, G., Guiot, J., Harrison, S. P., and Colin Prentice, I.: The climate of Europe 6000 years ago, Clim. Dynam., 13, 1-9, 1997.

Chen, L., Zonneveld, K. A. F., and Versteegh, G. J. M.: Short term climate variability during "Roman Classical Period" in the eastern Mediterranean, Quaternary Sci. Rev., 30, 3880-3891, 2011.

Combourieu-Nebout, N., Paterne, M., Turon, J. L., and Siani, G.: A high resolution record of the last deglaciation in the Central Mediterranean Sea: Paleovegetation and Paleohydrological evolution, Quaternary Sci. Rev., 17, 303-317, 1998.

Correggiari, A., Cattaneo, A., and Trincardi, F.: Depositional patterns in the Holocene Po Delta system, in: River Deltas: Concepts, Models and Examples, edited by: Bhattacharya, J. P. and Giosan, L., Society of Economic Paleontologists and Mineralogists Special Publication, 83, 365-392. 2005.

Curry, W. B. and Oppo, D. W.: Glacial water mass geometry and the distribution of $\delta^{13} \mathrm{C}$ of $\Sigma \mathrm{CO}_{2}$ in the western Atlantic Ocean, Paleoceanography, 20, PA1017, doi:10.1029/2004PA001021, 2005.

Debret, M., Bout-Roumazeilles, V., Grousset, F., Desmet, M., McManus, J. F., Massei, N., Sebag, D., Petit, J.-R., Copard, Y., and Trentesaux, A.: The origin of the 1500-year climate cycles in Holocene North-Atlantic records, Clim. Past, 3, 569-575, doi:10.5194/cp-3-569-2007, 2007.

Debret, M., Sebag, D., Crosta, X., Massei, N., Petit, J.-R., Chapron, E., and Bout-Roumazeilles, V.: Evidence from wavelet analysis for a mid-Holocene transition in global climate forcing, Quaternary Sci. Rev., 28, 2675-2688, 2009.

De Lange, G. J., Thomson, J., Reitz, A., Slomp, C. P., Principato, M. S., Erba, E., and Corselli, C.: Synchronous basin-wide formation and redox-controlled preservation of a Mediterranean sapropel, Nat. Geosci., 1, 606-610, 2008.

Dermody, B. J., de Boer, H. J., Bierkens, M. F. P., Weber, S. L., Wassen, M. J., and Dekker, S. C.: A seesaw in Mediterranean precipitation during the Roman Period linked to millennialscale changes in the North Atlantic, Clim. Past, 8, 637-651, doi:10.5194/cp-8-637-2012, 2012.

Digerfeldt, G., Sandgren, P., and Olsson, S.: Reconstruction of Holocene lake-level changes at Lake Xinias, central Greece, The Holocene, 17, 361-367, 2007.

Duplessy, J. C.: Isotope studies, in: Climatic change, edited by: Gribins, J., Cambridge Univ. Press, London, 46-67, 1978.

Duplessy, J. C., Shackleton, N. J., Fairbanks, R. G., Labeyrie, L., Oppo, D., and Kallel, N.: Deep water source variations during the last climatic cycle and their impact on the global deep water circulation, Paleoceanography, 3, 343-360, 1988.

Duplessy, J. C., Bard, E., Arnold, M., Shackleton, N. J., Duprat, J., and Labeyrie, L. D.: How fast did the ocean-atmosphere system run during the last deglaciation?, Earth Planet. Sci. Lett., 103, 41-54, 1991.

Eastwood, W. J., Leng, M. J., Roberts, N., and Davis, B.: Holocene climate change in the eastern Mediterranean region: a comparison of stable isotope and pollen data from Lake Gölhisar, southwest Turkey, J. Quaternary Sci., 22, 327-341, 2007. 
Emeis, K. C., Struck, U., Schulz, H. M., Rosenberg, R., Bernasconi, S., Erlekeuser, H., Sakamoto, T., and Martinez-Ruiz, F.: Temperature and salinity variations of Mediterranean Sea surface waters over the last 16000 years from records of planktonic stable oxygen isotopes and alkenone unsaturation ratios, Palaeogeogr. Palaeocl., 158, 259-280, 2000.

Essallami, L., Sicre, M. A., Kallel, N., Labeyrie, L., and Siani, G.: Hydrological changes in the Mediterranean Sea over the last 30,000 years, Geochem. Geophy. Geos., 8, Q07002, doi:101029/2007GC001587, 2007.

Fontugne, M. and Calvert, S. E.: Late Pleistocene variability of the carbon isotopic composition of organic matter in the Eastern Mediterranean: monitor of changes in carbon sources and atmosphere $\mathrm{CO}_{2}$ concentrations, Paleoceanography, 7, 1-20, 1992.

Fontugne, M., Paterne, M., Calvert, S. E., Murat, A., Guichard, F., and Arnold, M.: Adriatic deep water formation during the Holocene: implication for the reoxygenation of the deep Eastern Mediterranean sea, Paleoceanography, 4, 199-206, 1989.

Fontugne, M., Arnold, M., Labeyrie, L., Paterne, M., Calvert, S. E., and Duplessy, J. C.: Palaeoenvironment, Sapropel chronology and Nile river discharge during the last 20000 years as indicated by deep sea sediment records in the Eastern Mediterranean, in: "Late Quaternary Chronology and paleoclimates of the Eastern Mediterranean", edited by: Bar-Yosef, O. and Kra, R. S., Radiocarbon, 75-88, 1994.

Frignani, M., Langone, L., Ravaioli, M., Sorgente, D., Alvisi, F., and Albertazzi, S.: Fine sediment mass balance in the western Adriatic continental shelf over a century time scale, Mar. Geol., 222-223, 113-133, 2005.

Frigola, J., Moreno, A., Cacho, I., Canals, M., Sierro, F. J., Flores, J. A., Grimalt, J. O., Hodell, D. A., and Curtis, J. H.: Holocene climate variability in the western Mediterranean region from a deep water sediment record, Paleoceanography, 22, PA2209, doi:10.1029/2006PA001307, 2007.

Frisia, S., Borsato, A., Mangini, A., Spötl, C., Madonia, G., and Sauro, U.: Holocene climate variability in Sicily from a discontinuous stalagmite record and the Mesolithic to Neolithic transition, Quaternary Res., 66, 388-400, 2006.

Giorgi, F. and Lionello, P.: Climate change projections for the Mediterranean region, Global Planet. Change, 63, 90-104, 2008.

Giraudi, C.: Middle to Late Holocene glacial variations, periglacial processes and alluvial sedimentation on the higher Apennine massifs (Italy), Quaternary Res. 64, 176-184, 2005a.

Giraudi, C.: Late-Holocene alluvial events in the Central Apennines, Italy, The Holocene, 15-5, 768-773, $2005 \mathrm{~b}$.

Giraudi, C., Magny, M., Zanchetta, G., and Drysdale, R. N.: The Holocene climatic evolution of the Medtirreanean Italy: a review of the geological continental data, The Holocene, 21, 105-117, 2011.

Giunta, S., Negri, A., Morigi, C., Capotondi, L., Combourieu Nebout, N., Emeis, K. C., Sangiorgi, F., and Vigliotti, L.: Coccolithophorid ecostratigraphy and multi-proxy paleoceanographic reconstruction in the Southern Adriatic Sea during the last deglacial time (Core AD91-17), Palaeogeogr. Palaeocl., 190, 3959, 2003.

Grauel, A. L. and Bernasconi, S. M.: Core-top calibration of $\delta^{18} \mathrm{O}$ and $\delta^{13} \mathrm{C}$ of $\mathrm{G}$. ruber (white) and $\mathrm{U}$. mediterranea along the southern Adriatic coast of Italy, Mar. Micropal., 77, 175-186, 2010.
Haas, J. N., Richoz, I., Tinner, W., and Wick, L.: Synchronous Holocene climatic oscillations recorded on the Swiss Plateau and at timberline in the Alps, The Holocene 8, 301-309, 1998.

Heiri, O., Tinner, W., and Lotter, A. F.: Evidence for cooler European summers during periods of changing meltwater flux to the North Atlantic, Proc. Natl. Acad. Sci., 101, 15285-15288, 2004.

Holzhauser, H., Magny, M., and Zumbühl, H.: Glacier and lakelevel variations in west-central Europe over the last 3500 years, The Holocene, 15, 789-801, 2005.

Hoogakker, B. A. A., Chapman, M. R., McCave, I. N., Hillaire-Marcel, C., Ellison, C. R. W., Hall, I. R., and Telford, R. J.: Dynamics of North Atlantic Deep Water masses during the Holocene, Paleoceanography, 26, PA4214, doi:10.1029/2011PA002155, 2011.

Jackson, M. G., Oskarson, N., Trønnes, R. G., McManus, J. F., Oppo, D., Gronveld, K., Hart, S. R., and Sachs, J. P.: Holocene loess deposition in Iceland: Evidence for millennialscale atmosphere-ocean coupling in the North-Atlantic, Geology, 33, 509-512, 2005.

Joerin, U. E., Stocker, T. F., and Schlüchter, C.: Multicentury glacier fluctuations in the Swiss Alps during the Holocene, The Holocene, 16, 697-704, 2006.

Johnsen, S. J., Clausen, H. B., Dansgaard, W., Fuhrer, K., Gundestrup, N., Hammer, C. U., Iversen, P., Jouzel, J., Stauffer, B., and Steffensen, J. P.: Irregular glacial interstadials recorded in a new Greenland ice core, Nature, 359, 311-313, 1992.

Jorissen, F. J., Asioli, A, Borsetti, A. M., Capotondi, L., De Visser, J. P., Hilgen, F. J., Rohling, E. J., Van der Borg, K., VergnaudGrazzini, C., and Zachariasse, W. J.: Late Quaternary central Mediterranean biochronology, Mar. Micropal., 21, 169-189, 1993.

Kallel, N., Paterne, M., Labeyrie, L. D., Duplessy, J. C., and Arnold, M.: Temperature and Salinity records of the Tyrrhenian Sea during the last 18000 years, Palaeogeogr. Palaeocl., 135, 97-108, 1997a.

Kallel, N., Paterne, M., Duplessy, J. C., Vergnaud-Grazzini, C., Pujol, C., Labeyrie, L. D., Arnold, M., Fontugne, M., and Pierre, C.: Enhanced rainfall on Mediterranean region during the last sapropel event, Ocean. Acta, 20, 697-712, 1997b.

Kotthoff, U., Muller, U. C., Pross, J., Schmiedl, G., Lawson, I. T., van de Schootbrugge, B., and Schulz, H.: Late Glacial and Holocene vegetation dynamics in the Aegean region: an integrated view based on pollen data from marine and terrestrial archives, The Holocene, 18, 1019-1032, 2008a.

Kotthoff, U., Pross, J., Muller, U. C., Peyron, O., Schmiedl, G., Schulz, H., and Bordon, A.: Climate dynamics in the borderlands of the Aegean Sea during deposition of Sapropel S1 deduced from a marine pollen record, Quaternary Sci. Rev., 27, 832-845, 2008 b

Kuhnt, T., Schmiedl, G., Ehrmann, W., Hamann, Y., and Hembleben, C.: Deep-sea ecosystem variability of the Aegean Sea during the past $22 \mathrm{kyr}$ as revealed by Benthic Foraminifera, Mar. Micropal., 64, 141-162, 2007.

Lambeck, K. and Chappell, J.: Sea level changes through the last glacial cycle, Science, 292, 679-686, 2001.

Levitus, S.: Climatological Atlas of the World Ocean, NOAA/ERL GFDL, Professional Paper 13, Princeton, N.J., 173 pp. (NTISPB83-184093), 1982. 
Levitus, S. and Boyer, T. P.: World Ocean Atlas 1994, Vol. 4, Temperature, NOAA Atlas NESDIS, 4, 129 pp., NOAA, Silver Spring, Md., 1994.

Luetscher, M., Hoffmann, D. L., Frisia, S., and Spötl, C.: Holocene glacier history from alpine speleothems, Milchbach cave, Switzerland, Earth Planet. Sci. Lett., 302, 95-106, 2011.

Mackensen, A., Rudolph, M., and Kuhn G.: Late Pleistocene deep-water circulation in the subantarctic eastern Atlantic, Global Planet. Change, 30, 197-229, doi:10.1016/S09218181(01)00102-3, 2001.

Magny, M.: Holocene climatic variability as reflected by midEuropean lake-level fluctuations, and its probable impact on prehistoric human settlements, QuatERNARY Int., 113, 65-79, 2004.

Magny, M.: Holocene fluctuations of lake levels in west-central Europe: methods of reconstruction, regional pattern, palaeoclimatic significance and forcing factors, Encyclopedia of Quaternary Geology, Elsevier, 1389-1399, 2006.

Magny, M., Bégeot, C., Guiot, J., and Peyron, O.: Contrasting patterns of hydrological changes in Europe in response to Holocene climate cooling phases, Quaternary Sci. Rev., 22, 1589-1596, 2003.

Magny, M., de Beaulieu, J. L., Drescher-Schneider, R., Vannière, B., Walter-Simonnet, A. V., Millet, L., Bossuet, G., and Peyron, O.: Climatic oscillations in central Italy during the last GlacialHolocene transition: the record from Lake Accesa, J. Quaternary Sci., 21, 311-320, 2006.

Magny, M., de Beaulieu, J. L., Drescher-Schneider, R., Vannière, B., Walter-Simonnet, A. V., Miras, Y., Millet, L., Bossuet, G., Peyron, O., Brugiapaglia, E., and Leroux, A.: Holocene climate changes in the central Mediterranean as recorded by lake-level fluctuations at Lake Accesa (Tuscany, Italy), Quaternary Sci. Rev., 26, 1736-1758, 2007.

Magny, M., Bossuet, G., Ruffaldi, P., Leroux, A., and Mouthon, J.: Orbital imprint on Holocene palaeohydrological variations in west-central Europe as reflected by lake-level changes at Cerin (Jura Mountains, eastern France), J. Quaternary Sci., 26, 171177, 2011a.

Magny, M,. Vannière, B., Calo, C., Millet, L., Leroux, A., Peyron, O., Zanchetta, G., La Mantia, T., and Tinner, W.: Holocene hydrological changes in south-western Mediterranean as recorded by lake-level fluctuations at Lago Preola, a coastal lake in southern Sicily, Italy, Quaternary Sci. Rev., 30, 2459-2475, 2011 b.

Magny, M., Peyron, O., Sadori, L., Ortu, E., Zanchetta, G., Vannière, B., and Tinner, W.: Contrasting patterns of precipitation seasonality during the Holocene in the south- and north-central Mediterranean, J. Quaternary Sci., 27, 290-296, doi:10.1002/jqs, 1543, 2012a.

Magny, M., Joannin, S., Galop, D., Vannière, B., Haas, J. N., Bassetti, M., Bellintani, P., Scandolari, R., and Desmet, M.: Holocene palaeohydrological changes in the northern Mediterranean borderlands as reflected by the lake-level record of Lake Ledro, northeastern Italy, Quaternary Res., 77, 382-396, 2012 b.

Manca, B. B., Kovacevic, V., Gacic, M., and Viezzoli, D.: Dense water formation in the Southern Adriatic Sea and spreading into the Ionian Sea in the period 1997-1999, J. Mar. Syst., 33-34, 133-154, 2002.

Mangini, A. and Schlosser, P.: The formation of eastern Mediterranean sapropels, Mar. Geol., 72, 115-124, 1986.
Marino, G., Rohling, E. J., Sangiorgi, F., Hayes, A., Casford, J. L., Lotter A. F., Kucera, M., and Brinkhuis, H.: Early and middle Holocene in the Aegean Sea: interplay between high and low latitude climate variability, Quaternary Sci. Rev., 28, 3246-3262, 2009.

Mayewski, P. A., Rohling, E. J., Stager, J. C., Karlen, W., Maasch, K. A., Meeker, L. D., Meyerson, E. A., Gasse, F., van Kreveld, S., Holmgren, K., Lee-Thorp, J., Rosqvist, G., Rack, F., Staubwasser, M., Schneider, R. R., and Steig, E.: Holocene climate variability, Quaternary Res., 62, 243-255, 2004.

McDermott, F., Mattey, D. P., and Hawkesworth, C.: CentennialScale Holocene Climate Variability Revealed by a HighResolution Speleothem delta ${ }^{18} \mathrm{O}$ Record from SW Ireland, Science, 294, 1328-1331, 2001.

Mercone, D., Thomson, J., Croudace, I. W., Siani, G., Paterne, M., and Tröelstra, S.: Duration of S1, the most recent Eastern Mediterranean sapropel, as indicated by AMS radiocarbon and geochemical evidence, Paleoceanography, 15, 336-347, 2000.

Oldfield, F., Asioli, A., Accorsi, C. A., Mercuri, A.M., Juggins, S., Langone, L., Rolph, T., Trincardi, F., Wolff, G., Gibbs, Z., Vigliotti, L., Frignani, M., van der Post, K., and Branch, N.: A high resolution late Holocene palaeo environmental record from the central Adriatic Sea, Quaternary Sci. Rev., 22, 319-42, 2003.

Orlic, M., Gacic, M., and La Violette, P. E.: The currents and circulation of the Adriatic Sea, Ocean. Acta, 15, 109-124, 1992.

Overpeck, J. T., Webb III, T., and Prentice, I.: Quantitative interpretation of fossil pollen spectra: dissimilarity coefficients and the method of modern analogs, Quaternary Res., 23, 87-108, 1985.

Palinkas, C. M. and Nittrouer, C. A.: Clinoform sedimentation along the Apennine shelf, Adriatic Sea, Mar. Geol., 234, 245260, 2006.

Peyron, O., Goring, S., Dormoy, I., Kotthoff, U., Pross, J., de Bealieu, J. L., Drescher-Schneider, R., and Magny, M.: Holocene seasonality changes in the central Mediterranean region reconstructed from the pôllen sequences of Lake Accesa (Italy) and Tenaghi Philippon (Greece), The Holocene, 21, 131-147, 2011.

Pierre, C.: The oxygen and carbon isotope distribution in the mediterranean water masses, Mar. Geol., 153, 41-55, 1999.

Pinardi, N. and Masetti, E.: Variability of the large scale general circulation of the Mediterranean Sea from observations and modelling: a review, Palaeogeogr. Palaeocl., 158, 153-173, 2000.

Piva, A., Asioli, A., Trincardi, F., Schneider, R., and Vigliotti, L.: Late-Holocene climate variability in the Adriatic Sea (Central Mediterranean), The Holocene, 18, 153-167, 2008.

Poulain, P. M.: Drifter observations of surface circulation in the Adriatic Sea between December 1994 and March 1996, J. Mar. Syst., 20, 231-25, 1999.

Prell, W.: The stability of low-latitudes sea surface temperatures: an evaluation of the CLIMAP reconstruction with emphasis on the positive SST anomalies, p. 60, Technical Report. TR025, United States Department of Energy, Washington, DC, 1985.

Pross, J., Kotthoff, U., Müller, U. C., Peyron, O., Dormoy, I., Schmiedl, G., Kalaitzidis, S., and Smith, A. M.: Massive perturbation in terrestrial ecosystems of the Eastern Mediterranean region associated with the $8.2 \mathrm{kyr}$ B.P. climatic event, Geology, 37, 887-890, 2009.

Pujol, C. and Vergnaud-Grazzini, C.: Distribution patterns of live planktonic foraminifers as related to regional hydrography and productive systems of the Mediterranean Sea, Mar. Micropal., 
25, 187-217, 1995.

Raicich, F.: On the fresh water balance of the Adriatic coast, J. Mar. Syst., 9, 305-319, 1996.

Rasmussen, T. L. and Thomsen, E.: Holocene temperature and salinity variability of the Atlantic Water inflow to the Nordic seas, The Holocene, 8, 1223-1234, 2010.

Reed, J. M., Stevenson, A. C., and Juggins, S.: A multi-proxy record of Holocene climatic change in southwestern Spain: the Laguna di Medina, Cadiz, The Holocene, 11, 707-719, 2001.

Reimer, P. J., Baillie, M. G. L., Bard, E., Bayliss, A., Beck, J. W., Bertrand, C. J. H., Blackwell, P. G., Buck, C. E., Burr, G. S., Cutler, K. B., Damon, P. E., Edwards, R. L., Fairbanks, R. G., Friedrich, M., Guilderson, T. P., Hogg, A. G., Hughen, K. A., Kromer, B., McCormac, F. G., Manning, S. W., Ramsey, C. B., Reimer, R. W., Remmele, S., Southon, J. R., Stuiver, M., Talamo, S., Taylor, F. W., van der Plicht, J., and Weyhenmeyer, C. E.: IntCal04 Terrestrial radiocarbon age calibration, 26-0 ka BP, Radiocarbon, 46, 1029-1058, 2004.

Richie, J. C., Eyles, C. H., and Haynes, C. V.: Sediment and pollen evidence for an early to mid-Holocene humid period in the eastern Sahara, Nature, 314, 352-355, 1985.

Roberts, N., Reed, J. M., Leng, M. J., Kuzuguoglu, C., Fontugne, M., Bertaux, J., Woldring, H., Bottema, S., Black, S., Hunt, E., and Karabiyikoğlu, M.: The tempo of Holocene climatic change in the eastern Mediterranean region: new high resolution craterlake sediment data from central Turkey, The Holocene 11, 721736, 2001

Rogerson, M., Rohling, E. J., Weaver, P. P. E., and Murray, J. W.: Glacial to interglacial changes in the settling depth of the Mediterranean Outflow plume, Paleoceanography, 20, PA3007, doi:10.1029/2004PA001106, 2005.

Rohling, E. J.: Review and new aspects concerning the formation of eastern Mediterranean sapropels, Mar. Geol., 122, 1-28, 1994.

Rohling, E. J., Jorissen, F. J., and De Stigter, H. C.: 200 Year interruption of Holocene sapropel formation in the Adriatic Sea, J. Micropal., 16, 97-108, 1997.

Rohling, E. J., Mayewski, P. A., Abu-Zied, R. H,. Casford, J. S. L., and Hayes, A.: Holocene atmosphere-ocean interactions: Records from Greenland and the Aegean Sea, Clim. Dynam., 18, 587-593, 2002.

Rossi, V. and Vaiani, C. S.: Benthic foraminiferal evidence of sediment supply changes and fluvial drainage reorganization in Holocene deposits of the Po Delta, Italy, Mar. Micropal., 69, 106-118, 2008.

Rossignol-Strick, M., Nesteroff, W., Olive, P., and VergnaudGrazzini, C.: After the deluge: Mediterranean stagnation and sapropel formation, Nature, 295, 105-110, 1982.

Sadori, L. and Narcisi, B.: The post-glacial record of environmental history from Lago di Pergusa, Sicily, The Holocene, 11, 655672, 2001

Sarnthein, M., Winn, K., Jung, S. J. A., Duplessy, J. C., Labeyrie, L., Erlenkeuser, H., and Ganssen G.: Changes in east Atlantic deepwater circulation over the last 30,000 years: Eight time slice reconstructions, Paleoceanography, 9, 209-267, 1994.

Sangiorgi, F., Capotondi, L., and Brinkhuis, H.: A centennial scale organic-walled dinoflagellate cyst record of the last deglaciation in the South Adriatic Sea (Central Mediterranean), Palaeogeogr. Palaeocl., 186, 199-216, 2002.
Sangiorgi, F., Capotondi, L., Combourieu Nebout, N., Vigliotti, L., Brinkhuis, H., Giunta, S., Lotter, A. F., Morigi, C., Negri, A., and Reichart, G. J.: Holocene seasonal sea-surface température variations in the southern Adriatic Sea inferred from a multiproxy approach, J. Quaternary Sci., 18, 723-32, 2003.

Schmiedl, G., Kuhnt, T., Ehrmann, W., Emeis, K. C., Hamann, Y., Kotthoff, U., Dulski, P., and Pross, J.: Climatic forcing of eastern Mediterranean deep-water formation and benthic ecosystems during the past 22000 years, Quaternary Sci. Rev., 29, 30063020, 2010.

Schönfeld, J. and Zahn, R.: Late Glacial to Holocene history of the Meditarranean Outflow. Evidence from benthic Foraminiferal assemblages and stable isotopes at the Portuguese margin, Palaeogeogr. Palaeocl., 159, 85-111, 2000.

Scrivner, A. E., Vance, D., and Rohling, E. J.: New neodymium isotopic data quantifies Nile involvement in Mediterranean anoxic episodes, Geology, 32, 565-568, 2004.

Shackleton, N. J.: Attainment of isotopic equilibrium between ocean water and the benthonic foraminifera genus Uvigerina: isotopic changes in the ocean during the last glacial, Colloque CNRS no. 219, Centre National de la Recherche Scientifique, Paris, 203-210, 1974.

Shackleton, N. J., Hall, M. A., Line, J., and Shuxi, C.: Carbon isotope data in core V19-30 confirm reduced carbon dioxide concentration in the ice age atmosphere, Nature, 306, 319-322, 1983.

Siani, G., Paterne, M., Arnold, M., Bard, E., Métivier, B., Tisnerat, N., and Bassinot, F.: Radiocarbon reservoir ages in the Mediterranean Sea and Black Sea, Radiocarbon, 42, 271-280, 2000.

Siani, G., Paterne, M., Michel, E., Sulpizio, R., Sbrana, A., Arnold, M., and Haddad, G.: Mediterranean sea-surface radiocarbon reservoir age changes since the last glacial maximum, Science, 294, 1917-1920, 2001.

Siani, G., Sulpizio, R., Paterne, M., and Sbrana, A.: Tephrostratigraphy study for the last $18,000{ }^{14} \mathrm{C}$ years in a deep-sea sediment sequence for the South Adriatic, Quaternary Sci. Rev., 23, 24852500, 2004.

Siani, G., Paterne, M., and Colin, C.: Late Glacial to Holocene planktonic foraminifera bioevents and climatic record in the South Adriatic Sea, J. Quaternary Sci., 25, 808-821, doi:10.1002/jqs, 1360, 2010.

Stefani, M. and Vincenzi, S.: The interplay of eustasy, climate and human activity in the late Quaternary depositional evolution and sedimentary architecture of the Po Delta system, Mar. Geol., 222, 19-48, 2005.

Theron, R., Paillard, D., Cortijo, E., Flores, J. A., Vaquero, M., Sierro, F. J., and Waelbroeck, C.: Rapid reconstruction of paleoenvironmental features using a new multiplatform program, Micropaleontology, 50, 391-395, 2004.

Torrence, C. and Compo, G. P.: A practical guide to wavelet analysis, Bull. Am. Meteorol. Soc., 79, 61-78, 1998.

Voelker, A. H. L., Lebreiro, S. M., Schönfeld, J., Cacho, I., Erlenkeuser, H., and Abrantes, F.: Mediterranean outflow strengthening during northern hemis-phere coolings: A salt source for the glacial Atlantic?, Earth Planet. Sci. Lett., 245, 39-55, 2006.

von Grafenstein, U., Erlenkeuser, H., Muller, J., Jouzel, J., and Johnsen, S.: The cold event 8200 years ago documented in oxygen isotope records of precipitation in Europe and Greenland, Clim. Dynam., 14, 73-81, 1998. 
Waelbroeck, C., Labeyrie, L., Michel, E., Duplessy, J. C., McManus, J. F., Lambeck, K., Balbon E., and Labracherie, M.: Sealevel and deep water temperature changes derived from benthic foraminifera isotopic records, Quaternary Sci. Rev., 21, 295-305, 2002.

Zanchetta, G., Drysdale, R. N., Hellstrom, J. C., Fallick, A. E, Isola, I., Gagan, M. K., and Pareschi, M. T.: Enhanced rainfall in the western Mediterranean during deposition of sapropel 1: stalagmite evidence from Corchia cave (Central Italy), Quaternary Sci. Rev., 26, 279-286, 2007.

Zanchettin, D., Traverso, P., and Tomasino, M.: Po River discharges: a preliminary analysis of a 200-year time series, Clim. Change, 89, 411-433, doi:10.1007/s10584-008-9395-z, 2008.
Zanchetta, G., Giraudi, C., Sulpizio, R., Magny, M., Sadori, L., and Drysdale, R. N.: Constraining the onset of the Holocene "Neoglacial" over the central Italy using tephra layers, Quaternary Res., 78, 236-247, 2012.

Zhao, C., Yu, Z., and Zhao, Y.: Holocene climate trend, variability, and shift documented by lacustrine stable-isotope record in the northeastern United States, Quaternary Sci. Rev., 29, 1831-1843, 2010.

Zolitschka, B., Wulf, S., and Negendank, J. F. W.: CircumMediterranean lake records as archives of climatic and human history, Quaternary Int., 73, 1-5, 2000. 